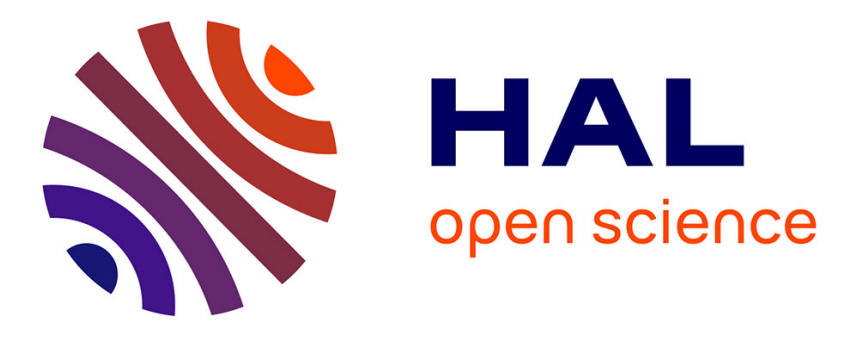

\title{
The challenge of integrative taxonomy of rare, deep-water, gastropods: the genus Exilia (Neoogastropoda: Turbinelloidea: Ptychatractidae)
}

\author{
Yuri I Kantor, Nicolas Puillandre, Philippe Bouchet
}

\section{- To cite this version:}

Yuri I Kantor, Nicolas Puillandre, Philippe Bouchet. The challenge of integrative taxonomy of rare, deep-water, gastropods: the genus Exilia (Neoogastropoda: Turbinelloidea: Ptychatractidae). Journal of Molluscan Studies, 2020, 86 (2), pp.120-138. 10.1093/mollus/eyz037 . hal-02559774

\section{HAL Id: hal-02559774 \\ https://hal.science/hal-02559774}

Submitted on 30 Apr 2020

HAL is a multi-disciplinary open access archive for the deposit and dissemination of scientific research documents, whether they are published or not. The documents may come from teaching and research institutions in France or abroad, or from public or private research centers.
L'archive ouverte pluridisciplinaire HAL, est destinée au dépôt et à la diffusion de documents scientifiques de niveau recherche, publiés ou non, émanant des établissements d'enseignement et de recherche français ou étrangers, des laboratoires publics ou privés. 
The challenge of integrative taxonomy of rare, deep-water, gastropods: the genus Exilia (Neoogastropoda: Turbinelloidea: Ptychatractidae)

Yuri I. Kantor ${ }^{1}$, Nicolas Puillandre ${ }^{2}$ and Philippe Bouchet ${ }^{2}$

\author{
${ }^{1}$ A.N. Severtsov Institute of Ecology and Evolution, Russian Academy of Sciences, Leninski prospect 33, \\ 119071 Moscow, Russian Federation; and \\ ${ }^{2}$ Institut Systématique Evolution Biodiversité (ISYEB), Muséum national d'Histoire naturelle, CNRS, \\ Sorbonne Université, EPHE, 57 rue Cuvier, CP 26, 75005 Paris, France
}

Running head: Integrative taxonomy of Exilia

(Received 2 May 2019; editorial decision 28 June 2019)

Correspondence: Y. Kantor; e-mail: kantor.yuri1956@gmail.com

ABSTRACT

According to a recent taxonomic revision by Kantor et al. (2001), the neogastropod genus Exilia Conrad, 1860 comprises ten mostly rare species that live at depths between 200 and 2,000 m. Adult Exilia measure between 30 and $90 \mathrm{~mm}$ in shell length and the genus is mostly represented in museum collections by empty shells. The abundance of this genus is low in the wild, but recent expeditions organized by the Muséum national d'Histoire naturelle have yielded several dozen specimens. These new collections include samples preserved for molecular studies Here, we present the results of the first molecular systematic study of Exilia. Our aim was to investigate the species limits proposed by Kantor et al. (2001) on the basis of shell and anatomical characters. Analysis of DNA sequence data for the cyctochrome $c$ oxidase I gene suggests that Exilia hilgendorfi, previously considered to be a single, polymorphic and broadly distributed species is a complex of at least six species (four of which we sequenced). Two of these species, Exilia cognata $\mathrm{n}$. sp. and E. fedosovi n. sp., are described as new to science. Exilia gracilior, E. claydoni and E. prellei are resurrected from the synonymy of Exilia hilgendorfi; of these three, only the last was sequenced. Exilia vagrans is a well-defined taxon, but our molecular systematic data shows that it consists of two distinct species, which occur sympatrically off Taiwan and are strikingly similar in shell and radular morphology; due to the absence of DNA sequence data from the type locality of E. vagrans (Vanuatu), it is unclear to which of these two species the name would apply. Exilia Karukera n. sp., which is conchologically very similar to E. vagrans, was discovered off Guadeloupe, represents the first record of the genus from the Atlantic. For E. elegans, which was previously known only from a single shell, we provide newdata including new distributional records (South Africa and the Mozambique Channel), details of the radula and DNA sequence data. 


\section{INTRODUCTION}

Like many medium- or large-sized predators, most neogastropods never occur in dense populations. This, combined with the difficulty accessing deep water, makes it difficult to sample and collect deep-sea predatory snails in biodiversity surveys. The gastropod genus Exilia Conrad, 1860 is a case in point. These snails, the adults of which measure between 30 and $90 \mathrm{~mm}$, live at depths between 200 and 2,000 m. In their review of the Recent species of the genus, Kantor et al. (2001) listed 325 specimens belonging to ten species. This material, he bulk of which is composed of empty shells (specimens preserved in alcohol make up only a small proportion) was collected on deep-water cruises conducted in the 1980s-1990s in the tropical Pacific and Indian Oceans and forms part of the holdings of several major museums. As Kantor et al. (2001) have noted: "with the exception of Benthovoluta [= Exilia] claydoni Harasewych, 1987, which was taken in moderate quantity in the 1980s as a by-product of shrimp trawling off Western Australia, material [of Exilia] is rare in museum collections". Any effort to carry out an integrative taxonomis study of such elusive animals is thus likely to be particularly challenging. In fact, in the almost 20 years since the Kantor et al. (2001) published their work, not a single paper has been published on any of the Recent species of Exilia.

At the time of the Kantor et al.'s revision, the genus Exilia was classified in the subfamily Ptychatractinae part of the family Turbinellidae. The Ptychatractidae was treated by Riedel (2000) as a family, a position followed by Bouchet \& Rocroi (2005). Subsequently, Fedosov et al.'s (2015) molecular phylogeny of mitriform neogastropods showed that the Ptychatractidae, as hitherto circumscribed, does not constitute a monophyletic group, with the two genera Ceratoxancus Kuroda, 1952 and Latiromitra Locard, 1897 now transferred to the family Costellariidae. The Ptychatractidae is currently (Bouchet et al., 2017) treated as a family of the superfamily Turbinelloidea. The status and limits of this family are currently uncertain, the type genus Ptychatractus Stimpson, 1865, having not been included in any molecular phylogenetic studies. The Ptychatractidae are therefore not discussed any further .

Kantor et al.'s 2001 study recognized ten Recent species of Exilia. Additionally, for Exilia hilgendorfi (Martens, 1897) (this taxon accounted for two thirds of the material available to them), Kantor et al. identified several geographically/bathymetrically localized forms. but the combination of nonplanktotrophic larval development and apparently transitional specimens or overlapping characters gave the impression of a continuum and, as a result, Kantor et al. concluded that they were dealing with a single, polymorphic, and broadly distributed species.

With the commencement of the Barcode of Life programme in 2004, the Muséum national d'Histoire naturelle (MNHN) began assembling large-scale collections of material for molecular systematic study as part of the workflow of their deep-sea cruises. Despite the low abundance of Exilia species in the wild, several dozen specimens were collected and preserved for molecular systematic study. Here, we to use a molecular phylogenetic approach to investigate the species limits proposed by Kantor et al. (2001). The present paper is not a revision of Exilia (several of the currently recognized species are not represented in the new material); it revisits the systematics of two of the species, E. hilgendorfi and E. vagrans Kantor $\&$ Bouchet, 2001, which are currently considered to be relatively widely distributed (E. hilgendorfi and $E$. vagrans Kantor \& Bouchet, 2001), and it provides new data on a third species, E. elegans (Barnard, 1959).

\section{MATERIAL AND METHODS}

\section{Material studied}


The new material on which the present paper is based was collected on the following deep-sea expeditions in the Indo-Pacific: MIRIKY, MAINBAZA and ATIMO VATAE (http://dx.doi.org/10.17600/10110040) in Madagascar and the Mozambique channel; AURORA 2007 in the Philippines; SALOMON 2 (http://dx.doi.org/10.17600/10110040) and SOLOMONBOA 3 (http://dx.doi.org/10.17600/7100070) in the Solomon Islands; TARASOC (http://dx.doi.org/10.17600/9100040) in the Tuamotu and Society archipelagoes; TAIWAN 2013, NanHai 2014 and DongSha 2014 in the South China Sea and Taiwan; KANACONO (http://dx.doi.org/10.17600/16003900) and KANADEEP (http://dx.doi.org/10.17600/17003800) in New Caledonia; and KARUBENTHOS 2015 (http://dx.doi.org/10.17600/15005400) in Guadeloupe (see expeditions. mnhn.fr for context and station lists). Until 2012, live specimens for molecular analysis were anaesthetized with an isotonic solution of $\mathrm{MgCl}_{2}$ and fixed in $96 \%$ ethanol. Specimens collected during later expeditions were processed with a microwave oven (Galindo et al., 2014): living molluscs were placed in a small volume of sea water; depending on specimen size, they were exposed to microwaves for 10-30 s; and immediately afterwards, bodies were extracted from the shells and immersed in $96 \%$ ethanol. Specimens described in this paper are deposited in the MNHN collection. Details for all sequenced material including BOLD (Barcode of Life Datasystem) and GenBank accession numbers are provided in Supplementary Material Table S1. Livecollected specimens and material collected in the form of shells alone are indicated in the Systematic Descriptions by 'lv' and 'dd', respectively. Other abbreviations used are: SL, shell length; and AL, xxxxxxx.

\section{Sequencing and phylogenetic reconstruction}

DNA was extracted and the barcode fragment of the cyctochrome $c$ oxidase I (COI) gene was sequenced following a standard protocol (Kantor et al., 2018). COI sequences were aligned manually, with no alignment gaps being detected. The final alignment was $658 \mathrm{bp}$ long. For the phylogenetic analyses, seven outgroups taxa were used (Supplementary Material Table S1). In all analyses, a GTR + I + G substitution model was used and the COI gene was divided into three partitions corresponding to the three codon positions. A maximum likelihood (ML) tree was reconstructed using RAxML v. 8.2.8 (Stamatakis, 2006); branch support was assessed using 1,000 bootstrap replicates. A Bayesian tree was obtained using MrBayes v. 3.2.6 (Huelsenbeck, Ronquist \& Hall, 2001); we used two runs each consisiting of eight Markov chains and the analysis was run for10,000,000 generations, with five swaps at each generation, a sampling frequency of one tree every 1,000 generations and a chain temperature of 0.02 . To be used as an input for the GMYC analysis (see below), An ultrametric tree was reconstructed using BEAST v. 1.8.3 (Drummond et al., 2012) as input for a GMYC analysis (see below). The BEAST analysis was run for 50,000,000 generations with a sampling frequency of one tree every 5,000 generations; relative divergence times were estimated using a relaxed log-normal clock with a coalescent prior and a constant population size, following the recommendations of Monaghan et al. (2009). For the MrBayes and BEAST analyses, convergence of each run was evaluated using Tracer v. 1.6 (Rambaut \& Drummond, 2014) (effective sample size values $>200$ ) and consensus trees were calculated after omitting the first $25 \%$ trees as burn-in. Branches were considered strongly supported when bootstrap (BS) and posterior probability (PP) values were $\geq 75$ and $\geq 0.95$. All phylogenetic analyses were performed on the Cipres Science Gateway (http://www. phylo.org/portal2).

Species delimitations were investigated using two methods: ABGD (Automatic Barcode Gap Discovery, Puillandre et al. 2012) and the single threshold version of the GMYC (General Mixed Yule Coalescent, Pons et al., 2006; Monaghan et al., 2009) model. We used the web version of ABDG 
(http://wwwabi.snv.jussieu.fr/public/abgd), with a p-distance model and all the other parameters set at default values. For the GMYC analysis (run on the server https://species.h-its.org) we used the BEAST tree as input.

\section{RESULTS}

\section{Molecular analysis and species delimitation}

Although the ML and Bayesian trees (Figs 1,2) are broadly similar in topology, there are some differences. Both trees show relationships between putative species 5, 6, 7 and 8 to be unresolved.

The two different methods of species delimitation (ABDG and GMYC) produced partly incongruent results. GMYC recognized eight putative species,. ABDG, in contrast recognized six putative species, with two of the six species each comprising two GMYC species (one consisting of GMYC species 1 and 2 and one comprising GMYC species 3 and 4). Putative species 5, 6, 7 and 8 were common to both species delimitation methods and correspond to strongly supported clades in both the ML and Bayesian trees. Putative species 1, 2 and 3 and the clade comprising species 1 and 2 are not strongly supported in the Bayesian tree. In the ML tree there is strong support for the monophyly of species 1, species 2 and the clade uniting these two species, but the clade corresponding to species 3 is not strongly supported.. Putative species 4 and the clade comprising species 3 and 4 are strongly supported in the Bayesian tree; of these two clades only putative species 4 is strongly supported in the ML tree.

The clade comprising putative species 1 and 2 consists of specimens from Taiwan, the South China Sea, the Philippines, the Solomon Islands and French Polynesia and is conchologically relatively heterogeneous. However, some characters are shared between geographically disparate populations; these characters include a spiral sculpture composed of thin and very distinct spiral cords, axial wrinkles on the subsutural ramp (produced by thickened growth lines) and a dark shell coloured with different shades of brown. Originally all these specimens were identified as Exilia vagrans Kantor \& Bouchet, 2001. The holotype of this species originates from Vanuatu, but no material from this archipelago was available for sequencing. Shell variability is high within populations from the same general locality and no geographical pattern was observed. As suggested by GMYC, it is possible that E. vagrans is a complex of several species, each of which corresponds to a distinct geographic population. At presently we are unable to apply the name E. vagrans in a restricted manner to any single one of these populations. For the timebeing, therefore, we tratet these populations as belonging to a single species, which we refer to as the $E$. 'vagrans' complex.

Putative species 3 is consists of several specimens from the South China Sea (339-633 m depth; Fig. 3) and a single sequenced specimen from the Solomon Islands (MNHN IM-2007-35817; Fig. 4A-C). Specimens from the South China Sea are rather homogeneous molecularly, although variable conchologically. The shells vary particularly in the degree of development of the axial ribs on the later whorls of the teleoconch and in the degree of development of the columellar plaits; the number of axial ribs on the penultimate whorl can range from 11-30, while the number of columellar plaits can range from 2 (in young specimens, Fig. 3H) to 4 (Fig. 3D). The colour of the shell varies from light yellowish to very light brown, with larger specimens tending to be darker. In comparison to other examples, the sequenced specimen from the Solomon Islands is larger (SL $73.7 \mathrm{~mm}$ ), darker, with more distinct spiral sculpture and 
a relatively broader, nearly biconic shell. Although morphologically distinct, this population is not recognized as a separate species by neither ABGD nor GMYC. In shell outline and sculpture pattern, putative species 3 is most similar to E. hilgendorfi from Japan, and we apply this name to it, with some reservations (see Systematic Description).

Putative species 4 consists of three morphologically distinct specimens from French Polynesia. These specimens are characterized by a light coloured, small to medium sized shell, with a characteristic narrow brown subsutural band. While both Bayesian and ML analyses show this species to be sister to putative species 3 (from the Solomons and South China Sea), These two species are conchologically very different. We, therefore, recognize putative species 4 as a separate species and since there is no available name that can be applied to it, we describe it as Exilia cognata n. sp. We note that very similar shells from New Caledonia were previously (Kantor et al., 2001) considered as a local morph of E. hilgendorfi.

Putative species 5 consists of nine sequenced specimens from the tropical western Atlantic, which are conchologically and anatomically very similar to E. vagrans. This species is here described as Exilia karukera n. sp.

Putative species 6 comprises four specimens from Mozambique and Madagascar and to this we applyt the name E. prellei (Bozetti, 2001), which was originally described from Madagascar (see Systematic Description). The species was previously (Kantor et al., 2001) considered to be a local morph of E. hilgendorfi.

A clade formed by two genetically similar specimens from the Coral Sea (Fig. 5) and one specimen from southern New Caledonia is recognized as a single species, putative species 7, by both the ABGD and GMYC analyses. The sequenced specimens (as well as two non-sequenced ones) are very similar conchologically and they are described as a new species, E. fedosovi $\mathrm{n}$. sp. The status of the specimen from New Caledonia is discussed further below.

Finally, putative species 8 , which is represented by three morphologically similar specimens (Fig. 3I) from the Mozambique Channel, was recognized as a separate species in all analyses. Conchologically the species similar to the holotype of E. elegans (Barnard, 1959) (described from a single specimen from off East London, South Africa), so we apply this name to it.

\section{SYSTEMATIC DESCRIPTIONS}

\section{Family PTYCHATRACTIDAE Stimpson, 1865}

\section{Genus Exilia Conrad, 1860}

Type species: Exilia pergracilis Conrad, 1860 (by monotypy), Midway Group, Eocene, Alabama, USA.

\section{Exilia hilgendorfi complex}

\section{Exilia hilgendorfi (Martens, 1897)}

(Figs 3A-H, 6A, C-D, 4)

Voluta hilgendorfi Martens, 1897: 176, pl. 17: 2 (holotype, Zoologische Museum Berlin 30277; not seen). Benthovoluta hilgendorfi-Okutani, 2000: 423, pl. 210: 3. 
Exilia hilgendorfi-Kantor et al., 2001: 104-106, figs 14A-E (in part, populations from Japan only; includes XXXX). Okutani, 2007: 946, pl. 237: 9.

Mitra plicifera Yokoyama, 1920: 48-49, pl. 2 : 16a-b.

Phenacoptygma kiiense Kuroda, 1931: 48, fig. 1.

Type material: For further data on types and type localities see Kantor et al. (2001: 104).

Other material examined (sequenced): Thirteen lv, South China Sea, NanHai 2014: 5 lv, Stn DW4100, $15^{\circ} 06^{\prime} \mathrm{N}, 116^{\circ} 32^{\prime} \mathrm{E}, 534-552$ m (MNHN-IM-2013-44048, MNHN-IM-2013-44050, MNHN-IM-201344056, MNHN-IM-2013-44059, MNHN-IM-2013-44596); 3 lv, Stn DW4102, 1503'N, $116^{\circ} 31^{\prime}$ E, 339 533 m (MNHN-IM-2013-44121, MNHN-IM-2013-44128, MNHN-IM-2013-44135); 5 lv, Stn DW4103, $15^{\circ} 05^{\prime} \mathrm{N}, 116^{\circ} 30^{\prime} \mathrm{E}, 633 \mathrm{~m}$ (MNHN-IM-2013-44176, MNHN-IM-2013-44180, MNHN-IM-2013-44187, MNHN-IM-2013-44188, MNHN-IM-2013-44197). One 1v, Solomon Islands SOLOMONBOA 3, DW2807, $9^{\circ} 15^{\prime} \mathrm{S}, 161^{\circ} 23^{\prime} \mathrm{E}$, 504-617 m (MNHN-IM-2007-35817).

Other material examined (not sequenced): Four lv, Solomon Islands, SALOMON 2: 2 lv, StnStn CP2228, 063'ㄱ, 156 ${ }^{\circ} 10^{\prime} \mathrm{E}, 609-625$ m (MNHN IM-2007-34057, MNHN IM-2007-34058); 1 lv, Stn CP2246,

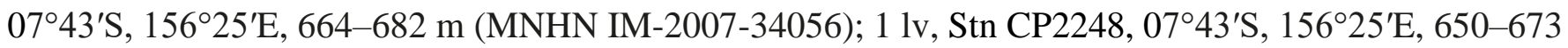
m (MNHN IM-2007-34061). Two lv, Solomon Islands, SALOMONBOA 3: 1 lv, Stn CP2835, 1041'S, $162^{\circ} 20^{\prime} \mathrm{E}, 735-862 \mathrm{~m}$ (MNHN IM-2007-35818); 1 lv, Stn CP2838, 10²5'S, 161 ${ }^{\circ} 20^{\prime} \mathrm{E}, 510-581 \mathrm{~m}$ (MNHN IM-2007-36332). Two lv, Chiba Prefecture, Uraga Channel, Japan, 300-350 m (MNHN IM-2019901, IM-2019-902).

Remarks: Kantor et al. (2001) considered Exilia hilgendorfi to be a very variable and broadly distributed species (ranging from Japan through the central Pacific to the Tasman Sea and New Zealand, as well as Madagascar and Réunion). In addition to Mitra plicifera and Phenacoptygma kiiense the synonymy includes three additional nominal species: Benthovoluta gracilior Rehder, 1967 (Philippines), B. claydoni Harasewych, 1987 (Western Australia), and B. prellei Bozzetti, 2001 (Madagascar). Kantor et al. (2001) recognized the high variability of this species and provided separate descriptions for populations from different part of its range. Nonetheless, these authors considered Exilia hilgendorfi to be a single, geographically variable species. However, the molecular systematic results presented here reveal that what was previously considered to be a single widely distributed species consists of at least four genetically and morphologically distinct species. Although our analyses do not include DNA sequence data for all these nominal species, our results suggest that E. gracilior and E. claydoni represent valid species and, until proved otherwise, are removed from the synonymy of $E$. hilgendorfi. Our results indicate that the four species discovered under the name E. hilgendorfi for the most part have relatively narrow geographical distributions; this is consistent with observation that they possess a paucispiral protoconch morphology. We thus now consider E. hilgendorfi in a much more restricted sense, applying the name to putative species 3. Even used in this sense, E. hilgendorfi is relatively variable in conchology and this is particularly true with respect to the number and development of the axial ribs (from 11 to 30 on the penultimate whorl) and columellar plaits (ranging from two in young specimens (Fig. 3H) to four in mature ones (Fig. 3D)).

The material we have sequenced originates from the South China Sea and the Solomon Islands, both of which are located a substantial distance from Japan. It is therefore possible that our species is 
distinct from the true E. hilgendorfi. To date, it has not been possible to obtain material of E. hilgendorfi from Japan, which is suitable for sequencing. Thus our use of the name E. hilgendorfi for putative species 3 is provisional.

Our material from the Solomon Islands consists of several conspecific specimens, of which only one was sequenced (Fig. 4). The shells of the non-sequenced specimens are larger (up to $85 \mathrm{~mm}$ ), darker in colour, have more distinct spiral cords and a less pronounced subsutural ramp than sequenced one. Another distinctive character of the non-sequenced specimens is that the axial ribs are present only on the adapical teleoconch whorls and very weak or absent on last whorl. These differences may have led to the recognition of the Solomon Islands population as a separate species, but genetically their divergence from the South China Sea specimens is low and morphologically similar specimens are found in both populations (compare Figs 3C-D and 4-I). Very similar shells were previously recorded from Tonga (Fig. $4 \mathrm{~J}$ ); these were considered to be a local morph of E. hilgendorfi (Kantor et al., 2001). It is interesting to note that the specimens from the Solomon Islands are actually more similar in shell shape, sculpture and size to specimens from Japan (Fig. 4H-I) than they are to those from the South China Sea. We were able to re-examine two Japanese specimens, collected at depths of 300-350 m from the Uraga Channel, Chiba Prefecture, Honshu. These have somewhat heavier, coarser shells, with the number of columellar plaits ranges from two to four (for a specimen with four columellar plaits, see Fig. 4H-I).

Our specimens from the South China Sea (Fig. 3) do not reach the same size $(60 \mathrm{~mm} v \mathrm{~s}$ upto $80 \mathrm{~mm}$ for E. hilgendorfi in Japan) and are clearly much lighter in colour. Although Japanese E. hilgendorfi tend to be dark chestnut brown, Okutani (2000: pl. 210:, fig. 3; 2017: pl. 237: fig. 9) illustrated a relatively light specimen; that latter is rather similar to darker shelled examples from our South China Sea material.

The radula of a specimen from the South China Sea (MNHN IM-2013-44180, SL 43.4 mm; Fig. 6A) is about $940 \mu \mathrm{m}$ long (5.6\% of AL without canal), $150 \mu \mathrm{m}$ wide ( $0.88 \%$ of AL without canal) and consists of about 70 rows of teeth. Rachidian teeth with arched anterior margin and medium broad lateral flaps; central part of the teeth with three broadly spaced cusps, central slightly longer than lateral ones. Lateral teeth unicuspid, with large, curved pointed cusp. The radula of this specimen is morphologically similar to theschematic line drawing in Habe (1952: 132, fig. 7), which illustrates the radula of a Japanese specimen.

In a specimen from the Solomon Islands (MNHN IM-2007-36332, SL $88.7 \mathrm{~mm}$ ), the radula is seemingly teratological (Fig. 6C-D). It is $2.7 \mathrm{~mm}$ long (7\% of AL without canal), around $260 \mu \mathrm{m}$ wide ( $0.67 \%$ of AL without canal) and consists of about 100 rows of teeth. Rachidian teeth with weakly concave anterior margin and medium narrow lateral flaps; central part of teeth with three broadly spaced and rather short cusps, central (shortest) and left cusps subdivided into irregularly shaped denticles and varying from row to row. Lateral teeth unicuspid, with large curved pointed cusp; on outer edge of some cusps several irregularly spaced blunt and short outgrowths.

Distribution: East coast of Japan, from the Boso peninsula and Hachijo Island southwards (50-480 m depth) (Higo et al., 1999) to the South China Sea (339-633 m depth) and the Solomon Islands (504-862 m depth). The records from Vanuatu and Tonga (Kantor et al., 2001) have to be confirmed by molecular data.

Exilia prellei (Bozzetti, 2001)

(Fig. 7)

Benthovoluta prellei Bozzetti, 2001: 19 (off Tulear, Madagascar; holotype MNHN IM-2000-30286). 
Exilia hilgendorfi-Kantor et al., 2001: 109-111, figs 17, 21 (in part, populations from the SW Indian Ocean only; includes XXX; not Martens, 1897).

Exilia hilgendorfi s. l.-Fedosov et al., 2015: 340 (in part, includes XXX).

Other material examined (sequenced): Four lv, northern Madagascar, MIRIKY: 1 lv, Stn CP3180, 12 ${ }^{\circ} 51^{\prime} \mathrm{S}$,

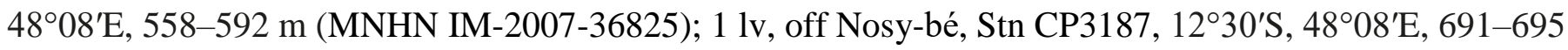
m (MNHN IM-2007-36878); 1 lv, Stn CP3221, 1247'S, 4808'E, 782 m (MNHN IM-2007-38061); 1 lv Stn CP3250, $15^{\circ} 22^{\prime} \mathrm{S}, 4^{\circ} 00^{\prime} \mathrm{E}, 493-750 \mathrm{~m}$ (MNHN IM-2007-38211).

Other material examined (not sequenced): 39 lots, totalling about 90 specimens, Madagascar (for details see Kantor et al., 2001: 109).

Remarks: Benthovoluta prellei Bozzetti, 2001 was described from Madagascar (from 'Tulear'; no depth given) based on a single shell lacking the protoconch (the holotype; Fig. 7J). The shell is broad, with shoulder angulated, last whorl lacking distinct axial ribs and with two columellar plaits and traces of a third one. In comparison to the holotype, our sequenced specimens are much smaller (up to $65 \mathrm{~mm} \mathrm{vs} 90.5 \mathrm{~mm}$ ) and more slender, but similar in sculpture and general shell outline. Our non-sequenced material includes larger specimens, up to $85 \mathrm{~mm}$. In shells of similar size, the axial ribs may be present or nearly absent on the last whorl, so cannot be considered a diagnostic character. Specimens of similar SL may have two or three columellar plaits.

We consider the holotype to be an unusually broad and large specimen of E. prellei. Exilia prellei corresponds in part to what Kantor et al. (2001: 109-111, figs 17C-D) had reported from the southwestern Indian Ocean as E. hilgendorfi. In addition to the recently collected material (including specimens sequenced by us), E. prellei is represented by extensive collections made during commercial shrimp surveys of the Madagascan side of the Mozambique Channel. The material examined by us shows substantial variation in the strength of the spiral sculpture, which varies from very weak in some specimens (Figs 7A-B) to strong and distinct in others. In larger specimens, the cords are more broadly spaced out on the last and penultimate whorls, with interspaces between some of the cords being equivalent to the width of individual cords. The number of columellar plaits varies from two to three, with large specimens tending to have three. Shell colour varies from light straw in the holotype to tan in other specimens.

The anatomy and radula were previously examined by Kantor et al. (2001: 92-94, figs 6A-G, 11A$\mathrm{B}, 12 \mathrm{C}$ ) in two specimens. The radula consists of 70-85 transverse rows of teeth and in width is 1.0-1.3\% of the aperture height. The rachidian teeth have the basal part slightly arched anteriorly, with broad lateral flaps and three sharp cusps on the anterior edge of the basal part; the tips of the cusps are distinctly tapering. Lateral teeth unicuspid with a short base.

Distribution: Mozambique Channel off Madagascar (310-750 m depth).

\section{Exilia cognata new species}

(Fig. 8)

Exilia hilgendorfi s. l.-Fedosov et al., 2015: 340 (in part, includes XXXX). 
Type material: Holotype (lv; sequenced), Huahine, Society Islands, French Polynesia, TARASOC, Stn DW3426, $16^{\circ} 40^{\prime} \mathrm{S}, 151^{\circ} 02^{\prime} \mathrm{W}, 801-874 \mathrm{~m}$ (MNHN IM-2007-38720).

Other material examined (sequenced): One lv, Kaukura, Tuamotu Islands, TARASOC, Stn DW3379, $15^{\circ} 38^{\prime} \mathrm{S}, 146^{\circ} 54^{\prime} \mathrm{W}, 800 \mathrm{~m}$ (MNHN IM-2007-39401). One lv, Tahiti, Society Islands, TARASOC, Stn DW3493, $17^{\circ} 28^{\prime} \mathrm{S}, 149^{\circ} 26^{\prime} \mathrm{W}, 556-565 \mathrm{~m}$ (MNHN IM-2007-38603).

Other material examined (not sequenced): Two lv, Raiatea, Society Islands, TARASOC, Stn DW3451, $16^{\circ} 53^{\prime} \mathrm{S}, 151^{\circ} 21^{\prime} \mathrm{W}, 440-490 \mathrm{~m}$ (MNHN IM-2007-38702, MNHN IM-2007-38703).

Etymology: Name refers to the fact that the new species had previously been considered a form of $E$. hilgendorfi; from the Latin adjective cognatus, meaning 'related'

\section{ZooBank registration: urn:Isid:zoobank.org:act:F2829094-F63D-45A0-B5DB-EC59512F0052.}

Diagnosis: Shell medium-sized for genus, length up to $58 \mathrm{~mm}$, fusiform. Axial sculpture of distinct ribs, extending suture to suture on teleoconch whorls, disappearing on shell base. Spiral sculpture of distinct, subequal, closely spaced, cords, stronger below shoulder. Shell greyish to very light olive with a narrow, light brown, subsutural band (more pronounced on penultimate and last whorls) and a broader, less distinct band on shell base and adapical part of canal.

Description (holotype): Shell small, fusiform, thin, with spire moderately high and turreted, whorls concave above shoulder and suture shallow yet distinct, adpressed and somewhat wavy; initial 1.5 whorls constitute protoconch, subsequent 8 whorls, teleoconch. Whorls of spire weakly convex below shoulder; last whorl strongly convex below shoulder. Protoconch (diameter $0.77 \mathrm{~mm}$ diameter, exposed height 0.70 $\mathrm{mm}$ ) paucispiral, tall, globose, light brown and with large nucleus; surface mostly eroded, but where intact, spiral striation evident. Protoconch/teleoconch transitionmarked by an opisthocyrt rib. Teleoconch sculpted with strong, nearly opisthocline, ribs extending suture to suture, but not apparent on shell base; ribs number 12 on first two teleoconch whorls, 13 on third whorl and remain constant on later whorls; an additional weak, short riblet may be visible on the subsutural ramp of the interspaces between primary ribs. Spiral sculpture of distinct, subequal, closely spaced, cords, which are weakly rounded on top and more pronounced below shoulder; cords gradually increases from five on first teleoconch whorl to 11 on penultimate whorl; cords hardly discernible on subsutural ramp of last whorl, where they number 40 in total (including 16 on canal), 1.5-2 x narrower in width on shell base and canal than on shell periphery; cords absent on anterior part of canal. Aperture ovate, tapering posteriorly, without canal comprises 0.3 of total SL.. Outer lip thin, evenly convex except on most of the adapical part, corresponding to subsutural ramp, partially broken. Siphonal canal narrow, long, nearly straight, crossing the coiling axis. Parietal wall and columella with narrow thin glossy callus; columella with traces of two very weak equally developed plaits, not seen in apertural view. Shell covered with peeling periostracum, which is absent on top of axial ribs (Fig. 7C). Shell greyish with a narrow, very light brown, subsutural band that is more pronounced on penultimate and last whorls; a broader, less distinct band on shell base and adapical part of canal.

Dimensions: total height $29.5 \mathrm{~mm}$, height of last whorl $20.3 \mathrm{~mm}$, aperture height without canal $9.0 \mathrm{~mm}$, diameter $9.8 \mathrm{~mm}$. 
Remarks: Exilia cognata $n$. sp. is rather uniform in shell characters. Larger specimens tend to have a darker last whorl, which can be tan in colour, but a darker subsutural band is always present. Some variation in the width of spiral cords, which overall are narrower on the subsutural ramp; a much narrower secondary cord may be evident between the primary ones. Axial ribs are weak or absent on the posterior part of the last whorl of large specimens. Exilia cognata $\mathrm{n}$. sp. reaches a height of $57.8 \mathrm{~mm}$.

Specimens from off southern New Caledonia (Kantor et al., 2001 identified these as "shallow-water populations of Exilia hilgendorfii from New Caledonia") are broadly similar to E. cognata $\mathrm{n}$. sp. in general shape, although slightly darker in colour, but differ from the new species in having a slightly larger and lighter protoconch. Without molecular data, the status of these New Caledonian specimens remains unresolved.

Exilia cognata n. sp. differs from E. hilgendorfi and E. biconica in having a smaller, lighter shell with a brown subsutural band. The combination of medium sized, light coloured shell with darker brown subsutural band distinguishes it from other congeneric species.

Distribution: So far this species is known only from the Society and Tuamotu Islands (490-801 m depth).

\section{Exilia fedosovi new species}

(Figs 6E-F, 9)

Type material: Holotype (lv; sequenced), S Lansdowne Bank, Coral Sea, KANADEEP 1, Stn CP5050, $20^{\circ} 52^{\prime} \mathrm{S}, 160^{\circ} 59^{\prime} \mathrm{E}, 600 \mathrm{~m}$ (MNHN IM-2013-48246).

Other material examined (sequenced): One lv, S Lansdowne Bank, Coral Sea, KANADEEP, Stn CP5053, $21^{\circ} 03^{\prime} \mathrm{S}, 161^{\circ} 07^{\prime} \mathrm{E}, 730-790 \mathrm{~m}$ (MNHN IM-2013-48171, radula and anatomy examined). Exilia aff. fedosovi, 1 lv, N Antigonia Seamount, Norfolk Ridge, off New Caledonia, KANACONO, Stn CP4750, $23^{\circ} 17^{\prime} \mathrm{S}, 167^{\circ} 56^{\prime} \mathrm{E}, 750-850 \mathrm{~m}$ (MNHN IM-2013-66087).

Other material examined (non sequenced): Two lv, S Lansdowne Bank, Coral Sea, KANADEEP: 1 lv, Stn CP5050, 2052'S, 16059'E, 600 m (MNHN IM-2013-65972); 1 lv, Stn CP5054, 21 ${ }^{\circ} 02^{\prime} \mathrm{S}, 1^{\circ} 61^{\circ} 11^{\prime} \mathrm{E}, 810$ 840 m (MNHN IM-2013-65654). One dd, CORAIL2, Stn DE15, 2051'S, 16056'E, 580-590 m.

Etymology: Named after our colleague Alexander Fedosov, A.N. Severtsov Institute of Ecology and Evolution, in recognition of his work in the field of marine caenogastropod molecular systematics and taxonomy.

ZooBank registration: urn:lsid:zoobank.org:act:03DCEF1B-75E0-4FFB-AF07-660E388496EC.

Diagnosis: Shell small, up to $29.5 \mathrm{~mm}$ long, narrowly fusiform and white. Axial sculpture of distinct ribs on adapical teleoconch whorls, extending from suture to suture, weaker or absent on last whorl and shell base. Spiral sculpture of low, weak cords that may be absent on the last whorl. Two very weak columellar plaits. 
Description (holotype): Shell small, thin, very slender, narrowly fusiform, with high turreted spire, whorls concave above shoulder and weakly convex below and deep, impressed, somewhat wavy, suture; first 1.5 whorls constitutes the protoconch, the remaining 8 whorls, the teleoconch. Last whorl evenly convex due to undefined subsutural ramp. Protoconch (diameter $0.8 \mathrm{~mm}$, exposed height $0.73 \mathrm{~mm}$ ) paucispiral, tall, globose, with large nucleus, and traces of spiral striation. Protoconch/teleoconch transition marked by an opisthocyrt rib. Teleoconch sculpture consists of strong, nearly prosocline ribs which extend from suture to suture on three earliest (most adapical) teleoconch whorls and disappearing on subsutural ramp of later whorl; number of ribs (10-11) remains constant from first to antepenultimate whorl; ribs weaker on penultimate whorl, 14 in total, obsolete on last whorl. Spiral sculpture below shoulder consists of low, indistinct, closely spaced cordsthat are rounded on top.; spiral sculpture more pronounced on the adapical teleoconch whorls (four in total) and disappearing on posterior half of penultimate whorl; spiral cords on last whorl seen only at transition to canal and on canal (absent on anterior part of canal), very indistinct, around 15. In addition to spiral cords, there are numerous, irregularly spaced, and often oblique, grooves; these likely are traces of a hydroid colony. Aperture narrowly elongate, without canal constituting 0.31 of total SL, tapering posteriorly. Outer lip thin, partially broken. Siphonal canal narrow, long, crossing the coiling axis. Parietal wall and columella with moderately broad, thin and glossy callus. Columella with two very weak, equally developed, plaits, which are not visible when the aperture viewed head-on, but evident when shell is turned clockwise (Fig. 9B). Shell uniformly white. Dimensions: total height $25.5 \mathrm{~mm}$, height of last whorl $17.0 \mathrm{~mm}$, aperture height without canal $7.9 \mathrm{~mm}$, diameter $6.4 \mathrm{~mm}$. On the basis of a single specimen (MNHN IM-2013-48171, SL $23.7 \mathrm{~mm}$ ), the anatomy of the foregut is very similar to that of $E$. vagrans (Kantor et al., 2001: fig. 7). A minor difference is that the new species has a much narrower and longer anterior oesophagus; this forms several loops before passing through the nerve ring. Oesophagus strongly pigmented, brownish grey along its entire length. Buccal tube spanning about half the length of the proboscis; in contracted state, very thin, narrow and transparent. Radula (Fig. 6E) $0.74 \mathrm{~mm}$ long (10.5\% of AL without canal), approximately $140 \mu \mathrm{m}$ wide (2.0\% of AL without canal); consisting of about 60 rows of teeth. Rachidian teeth with arched anterior margin and medium broad lateral flaps; central part of teeth with three, broadly spaced and rather short, pointed cusps, central one of which is slightly shorter than the lateral ones. Lateral teeth unicuspid, with large, curved and pointed cusp.

Remarks: The specimens from the Coral Sea are conchologically very similar; the largest reaches $35 \mathrm{~mm}$ (Fig. 9G). All lack distinct spiral cords on the periphery of the last whorl. A white shell with very weak spiral sculpture (barely discernible on most of last whorl) separates E. fedosovi n. sp. from other known species of Exilia.

Our material of E. fedosovi n. sp. also includes a sequenced specimen from the Norfolk Ridge, which our molecular tree was shown to be sister to the two specimens from the Coral Sea (Fig. 9H-I); the pdistance between the Norfolk Ridge sample and the two Coral Sea specimens is low (2.3\%) and the former sample was assigned by both species delimitation methods to E. fedosovi n. sp., to which it is similar in general shell outline. The Norfolk Ridge specimen, however, differs from the Coral Sea material in a number of ways: the sculpture is different, the whorls of the spire are less convex, the axial ribs are more numerous (15-16 per whorl), the spiral cords are more distinct and, on the adapical part of the teleoconch whorls, they form nodes at intersections with the axial ribs; spiral cords are present at the periphery of the later whorls (but they are much less pronounced than on the shell base). The radula (Fig. 6F) also shows some differences. In the Norfolk Ridge specimen it is $1.25 \mathrm{~mm}$ long (10.4\% of AL without canal), $200 \mu \mathrm{m}$ wide (1.6\% of AL without canal) and has about 80 rows of teeth. Rachidian teeth differ slightly from those 
of E. fedosovi n. sp. in having broader flaps and a central cusp that is longer than the lateral ones. At present we have a single sequenced specimen from Norfolk Ridge and more material is necessary before the status of this population can be clarified.

Distribution: Presently confirmed as occurring only in the Coral Sea (590810 m depth); the same species may be also present in the vicinity of the Norfolk Ridge, off southern New Caledonia.

\section{Exilia vagrans complex}

\section{Exilia vagrans Kantor \& Bouchet, 2001}

(Fig. 5)

Exilia vagrans Kantor \& Bouchet, 2001: 119-122, figs 7, 12E-F, 23-24.

Exilia hilgendorfi s. l.-Fedosov et al., 2015: 340 (in part, includes XXXX).

Type material: Holotype (xx), off northeastern Malekula Island, Vanuatu, MUSORSTOM 8, Stn CP1076, $15^{\circ} 54^{\prime} \mathrm{S}, 167^{\circ} 30^{\prime} \mathrm{E}, 1100-1191 \mathrm{~m}$ ( MNHN IM-2000-20028).

Remarks: Exilia vagrans was originally recorded from Vanuatu (type locality), the Philippines, Wallis and Futuna, Fiji and the Loyalty Basin. The shell of this species was considered to differ from other species of Exilia by its spiral sculpture of "very thin but distinct spiral cords and strong microsculpture of incrementral riblets, particularly strong and raised in the subsutural sulcus" (Kantor et al., 2001: 121), salmon to chestnut colour and dark chestnut protoconch. These characters made $E$. vagransone of the most easily identifiable species of the genus. The situation has changed dramatically changed With the sequencing of a large number of specimens that were identified as E. vagrans on the basis of conchology. Our GMYC analysis indicates that we are dealing with a complex of two putative species (Fig. 1), one from Taiwan, the South China Sea and the Solomons and the oether from the Society Islands, the Philippines and Taiwan. The Taiwanese samples are particularly important for understanding the taxonomic status of this complex because they indicate these two are partly sympatric. The variability in shell morphology is relatively high, both between and within the two putative species delimited by GMYC. For instance, two morphologically divergent specimens and (Fig. 5: specimens (6) and (7)) from the Society Islands (MNHN IM-2007-38761) and Tuamotu fall MNHN IM-2007-38557) within the same clade. As is clear from Figure 5, both putative species have specimens with strong axial sculpture on the last whorl (e.g. specimens (3), (4) and (5) for the first species and (6), (8), (9) and (10) for the second species) and both species have a very weak or obsolete fold on the last whorl (e.g. specimens (1) and (2) for the first species and (7) for the second). The representatives of the two species, which lack axial folds on the last whorl, are similar to the holotype. The radulae and foregut morphology of the two putative species species is similar to the studied specimen from Vanuatu (Kantor et al., 2001).

In our study only the population(s) from Taiwan are represented by a large number of specimens, while only two-three specimens are available for the other taxa. There is unfortunately no sequenced material from Vanuatu, which is located within the possible area of overlapof the two species, with both species potentially co-occurring there. This at present is preventing the application of the name vagrans to one of the two species in particular. This issue can be resolved when DNA sequence data become available 
for the holotype and other specimens from the type locality (Vanuatu); the development of protocols that can successfully extract usable DNA from old museum material is ongoing, so otbtaining sequence data from the holotype and other historical material should be possible in the near future.

\section{Exilia karukera new species}

(Figs 6G-H, 10)

Type material: Holotype (lv; sequenced) off Guadeloupe, Lesser Antilles, KARUBENTHOS 2, Stn CP4617, 16²3'N, 6046’W, 830-874 m (MNHN IM-2013-61213).

Other material examined (sequenced): Eight lv, Guadeloupe, KARUBENTHOS 2: 1 lv Stn CP4608,

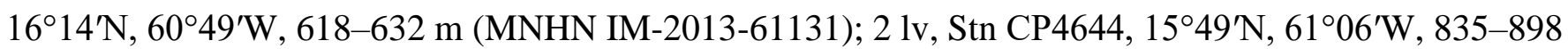
m (MNHN IM-2013-61540, MNHN IM-2013-61541); 2 lv, Stn DW4562, 16² 25’N, 6047’W, 549-677 m (MNHN IM-2013-60640, MNHN IM-2013-60641); 1 lv, Stn DW4576, 16²0’ N, 6054’ W, 456-545 m

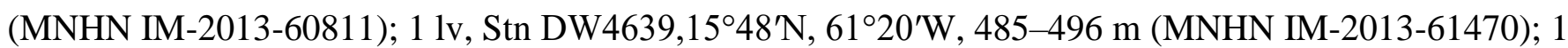

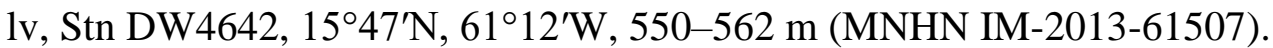

Other material examined (not sequenced): Two lv, Guadeloupe, XXXXXXX, Stn DW 4576, 16 ${ }^{\circ} 20^{\prime} \mathrm{N}$, 605’W, 456-545 m (MNHN IM-2013-61118, MNHN IM-2013-60810).

Etymology: Derived from 'Karukera' ('island of beautiful waters'), the name given to Guadeloupe by the Arawak Amerindians, who settled there in 300 AD. Used as noun in apposition.

ZooBank registration: urn:lsid:zoobank.org:act:92EA93B5-F485-47C4-90D4-BE84851EC6AB.

Diagnosis: Shell small, up to $35.5 \mathrm{~mm}$ long, narrow, fusiform. Axial sculpture of distinct ribs on all teleoconch whorls, weaker on last whorl and absent on shell base. Spiral sculpture of distinct low narrow cords on entire shell. Two very weak columellar plaits. Shell varying in colour from yellow to dark chestnut brown.

Description (holotype): Shell small, narrowly fusiform, thin but not fragile, with whorls that are concave above shoulder and weakly convex below and shallow impressed suture; first 1.5 whorls constitutes protoconch and remaining 6.5 whorls, the teleoconch. Protoconch (diameter $1.1 \mathrm{~mm}$, exposed height 0.53 $\mathrm{mm}$ ) paucispiral, smooth, with large bulbous nucleus. Transition from protoconch to teleoconch marked by several thin orthocline axial ribs. Teleoconch sculpture of narrow yet distinct opisthocline ribs crossed by numerous, much narrower, spiral cords.; microsculpture of strong, incremental riblets that are particularly thickened and raised on the subsutural ramp; number of primary ribs increases from 15 on first whorl to 18 on penultimate and last whorls. Spiral sculpture equally well defined on all teleoconch whorls consisting of low, narrow, somewhat wavy cords that are rounded above; cords closer on later whorls; interspaces between cords gradually diminish from $>1.5-2 \mathrm{x}$ cord width on first 4 teleoconch whorls to $1-1.5 \mathrm{x}$ on penultimate and last whorls; number of cords on exposed part of upper spire increases from six on first teleoconch whorl to 17 on penultimate whorl; cords absent on subsutural ramp of upper whorls and very weak on penultimate and last whorls; last adult whorl with about 65 cords, of which about 30 on siphonal canal, where they are about $1.5 \mathrm{x}$ wider than on whorl periphery, except on anterior tip of canal, where 
cords are very closely spaced. Aperture narrowly elongate, without canal comprises 0.33 of total shell height. Outer lip thin, nearly straight centrally and slightly concave at transition to canal. Siphonal canal rather wide, long, not crossing the coiling axis. Parietal wall and columella with very narrow, thin and glossy callus. Columella with two very weak, obtuse, equally developed, plaits, that are clearly visible when shell is rotated clockwise. Colour of protoconch and first three teleoconch whorls tan, gradually darkening to chestnut brown; a broad, ill-defined whitish band on shell base and canal (this appears to be the results of surface corrosion). Dimensions: total height $26.8 \mathrm{~mm}$, height of last whorl $17.7 \mathrm{~mm}$, aperture height without canal $8.8 \mathrm{~mm}$, diameter $7.7 \mathrm{~mm}$. Operculum as well as opercular scar absent. Anatomy of the digestive system very similar to that of E. vagrans. There are minor differences (these may be due to the conditions of fixation) with the new species showing the following characters: - more cylindrical proboscis (coniform in E. vagrans); a longer loop of the anterior oesophagus as it leaves the proboscis; narrower oesophagus Exilia fedosovi also has the salivary glands fused and completely covering the valve of Leiblein, which is smaller than in E. vagrans, and the gland of Leiblein is transversely subdivided into compartments. The glandular mid-oesophagus is very short, but due to its creamy colour contrasts with the dark-grey oesophagus. Buccal tube very thin, constituting about one-third the proboscis length, convoluted, obviously contractible and leading from the mouth to the much broader, spherical and relatively short buccal cavity; the buccal cavity has transparent walls. Radular diverticulum (i.e. posterior half of proboscis) has the odontophore deeply retracted within it and slightly protruding from the rear of the contracted proboscis. Radula (Fig. 6G-H) $0.93 \mathrm{~mm}$ long (10.6\% of AL without canal), around $150 \mu \mathrm{m}$ wide (1.7\% of AL without canal), consisting of about 55 rows of teeth. Rachidian teeth with strongly arched anterior margin and medium broad lateral flaps; central part of the teeth with three closely spaced, long, nearly equal, pointed cusps, the central cusp of which is slightly longer than the lateral ones. Lateral teeth unicuspid, with a large, curved and pointed cusp.

Remarks: The Specimens examined vary in how slendern they area, with larger specimens being stouter and relatively broader than smaller ones. Younger specimens have a lighter, yellowish to light brown shell. Protoconch may be very finely spirally striated. The species attains nearly $30 \mathrm{~mm}$ in length.

Exilia karukera n. sp. is superficially similar to the E. vagrans complex and this is especially true of the sculpture. However, the shell of E. karukera n. sp. is snaller in size $(29.5 \mathrm{~mm} v s$ over $65 \mathrm{~mm}$ for $E$. vagrans) and has a greater number of opisthocline axial ribs Unlike other species of Exilia, E. vagrans and E. karukera $\mathrm{n}$. sp. often carry epibiontic zoantharians. The differences between the two include a much smaller adult size in E. karukera n. sp. (29.5 $\mathrm{mm}$ vs over $65 \mathrm{~mm}$ in the rest of the E. vagrans complex), and more opisthocline axial ribs.

Distribution: Exilia karukera n. sp. is the only species of Exilia known from the Atlantic Ocean and so far is known only from off Guadeloupe (496-835 m depth).

\section{Exilia elegans (Barnard, 1959)}

(Figs 3I, 6B)

Fusivoluta elegans Barnard, 1959: 32, fig. 8a (off East London, South Africa, approximately 740 m; holotype, South African Museum A8803; Kantor et al., 2001, fig. 22H-I).

Exilia elegans-Kantor et al., 2001: 117-118, fig. 22H-J. 
Exilia krigei-Fedosov et al., 2015: 340 (not Kilburn, 1971).

Other material examined (sequenced): Three 1v, Mozambique Channel, 708-776 m.

Other material examined (not sequenced): XXX, Mozambique Channel, MAINBAZA, Stn CP3140, 2333' $\mathrm{S} ; 36^{\circ} 02^{\prime} \mathrm{E}, 886-898 \mathrm{~m}$ (MNHN IM-2007-38302).

Remarks: Fusivoluta elegans was described on the basis of a single, obviously immature shell. Our material matches the holotype and a second, previously examined (Kantor et al., 2001: fig. 22J) specimen from a site close to the type locality. Thus, applying the name E. elegans to the newly obtained material is straightforward. Our findings extend the distribution of the species northwards by just over $1000 \mathrm{~km}$. The radula (Fig. 6B) is similar to that in other species of Exilia. In E. elegans the rachidian teeth have a shallowly arched anterior margin, and broad lateral flaps, the centralrachidian teeth have three broadly spaced and narrowly pointed cusps (the central cusp is slightly longer and narrower than the lateral ones), and the lateral teeth are unicuspid, with the cusp large, curved and pointed.

Exilia elegans is most similar to E. krigei (Kilburn, 1971) from Mozambique, a nominal species that has yet to be sequenced; the main difference is that $E$. krige $i$ has a larger (nearly twice the size of $E$. elegans) and darker shell, with more pronounced axial ribs on the early whorls. The holotypes of Fusivoluta elegans and Benthovoluta krigei Kilburn, 1971 have been illustrated and their conchological differences discussed in detail by Kantor et al. (2001). The new material confirms Kantor et al.'s (2001) hypothesis that Fusivoluta elegans belongs in the genus Exilia..

Distribution: Known from off south-eastern Africa, ranging from South Africa to Mozambique (450-780 $\mathrm{m}$ depth).

\section{DISCUSSION}

\section{Hidden diversity of Exilia}

The molecular phylogenetic analyses presented here suggests that the morphology-based taxonomy of Exilia substantially underestimates species diversity. Our study includesonly three of the ten species (nine described and one undescribed) treated by Kantor et al. (2001): Exilia hilgendorfi, E. vagrans and E. elegans. Only the taxonomic extension of the latter is not modified as a result of the present study. Our molecular systematic data show that at least three of the geographical morphs of the highly variable taxon Exilia hilgendorfi constitute distinct species (E. prellei, E. cognata n. sp. and E. fedosovi n. sp.). The new data for E. hilgendorfi also suggests that the two nominal species E. gracilior and E. claydoni should be removed from the synonymy of E. hilgendorfi, at least until their status can be re-evaluated by sequencing of topotypic material. Thus, the name E. hilgendorfi contains at least four, and possibly even six, species. Furthermore, there are other morphologically distinct populations of ' $E$. hilgendorfi' that have yet to be sequenced and may represent additional species. However, our results also highlight the fact that caution is needed when using shell morphology for the discrimination of Exilia species. For example, specimens of Exilia from the Solomon Islands appear to represent a morphologically well-defined species that is distinct 
from E. hilgendorfi, but this is molecular systematic data indicate that the Solomon Islands Exilia is conspecific with population of E. hilgendorfi from the South China Sea. Thus, for the genus as a whole, shell-based species limits appear to be unreliable in many cases. Our work on other neogastropod taxa shows that species initially identified by by molecular characters are often characterized by distinctive and recognizable shell characters; examples in this respect include species in the genera Bathytoma (Puillandre et al., 2010a), Crassispira (Kantor et al., 2017), Lophiotoma (Puillandre et al., 2017) and Hemilienardia (Fedosov et al., 2016). Another example is the tonnoidean Bursa granularis, which was previously treated as a single, broadly distributed species, but is now considered to consist of four separate species (Sanders et al., 2017). However, as has been shown by Puillandre et al. (2010b) for Gemmuloborsonia, there are cases where species, which are clearly defined using molecular systematic characters, are not always recognizable on the basis of morphology.

That at least some morphologically distinctive populations of E. 'hilgendorfi' are in fact new species is perhaps not so surprising. What is more unexpected is is that the morphologically much more homogeneous taxon E. 'vagrans' consists of two distinct species. The very peculiar and seemingly diagnostic character - the pattern of spiral and axial sculpture - now appears to be shared at least by two Pacific species and the new species E. karukera n. sp. from the tropical Atlantic. Relationships between species in the $E$. 'vagrans' complex were not resolved a poorly supported clade $(\mathrm{PP}=0.59, \mathrm{BS}=84)$ and it is unclear if these species are sister taxa and if there are other species yet to be detected in this complex.

The discovery of E. karukera n. sp., the first confirmed representative of the genus in the tropical Atlantic, is of special interest. Fossil representatives of the genus are known from the Late Cretaceous and Eocene deposits of North America (Kantor et al., 2001). Thus, E. karukera may either belong to this ancient lineage or belong to one that have reached the Atlantic before the closure of the Panama isthmus. Exilia is represented in the eastern Pacific by there by E. blanda (Dall, 1908) from off Costa Rica, but this species and E. karukera are morphologically very different.

\section{Importance of integrative taxonomy}

Our molecular systematics-based study of the taxonomy of Exilia emphasizes the importance of new techniques in taxonomic studies. The molecular systematics revolution has brought about major change in the way that taxonomic research is carried out and it is now widely recognized that molecular data are often be essential for assessing intra- and inter-specific variability in taxonomic studies. Although it is possible to foresee a future in which the evaluation of molecular characters becomes a routine part of delimiting and describing species, at the present this is not the case for many taxa, including molluscs. In fact, the number of new species of molluscs for which DNA sequence data are available remains surprisingly low.

To test the impact of molecular data on molluscan alpha-taxonomy, Bouchet et al. (2016) screened two sets of 200 randomly selected descriptions of new species (published respectively in 2005-2009 and 2010-2014) and to assess what proportion of descriptions included molecular sequence data. The resulting figures of $1.5 \%$ for the 2005-2009 and 9\% for 2010-2014 suggest that while molecular sequence data are being used in alpha-taxonomy, this is still on a very modest scale. Puillandre et al. (2017) have noted that for the MNHN Mollusca collection, the first holotype associated with a DNA sequence was registered in 2008; since then 2,126 mollusc holotypes have been deposited in the collection, but only 3\% (65) are associated with a publicly available DNA sequence.

The relatively rare use of molecular sequence data in species delimitation and description is due to three key reasons. (1) While it is only in the last 15-20 years that molecular systematic methods have 
become widely available and reasonably inexpensive, the vast majority of molluscan collections were collected many years - or even decades - ago (Fontaine et al., 2012) and is mostly unsuitable for conventional Sanger sequencing. (2) Many species are represented in collections by empty shells alone. For example, $28.5 \%$ of 2,738 mollusc species sampled in an intensive biodiversity survey of coral reefs were represented by empty shells alone (Bouchet et al., 2002). A more astounding example is that $73 \%$ of 1,409 turrid species collected off New Caledonia at depths greater than $100 \mathrm{~m}$ were recovered only in the form of empty shells, a situation analogous to the "rare biosphere", of Sogin et al. (2006). (3) For many groups of molluscs, the only specialist/expert working on the group is often a citizen scientist ('amateur' taxonomist). Bouchet et al. (2016) found that, for 6,656 new species of marine molluscs described from 2000-2014, $40 \%$ of first authors were citizen scientists and that such workers were responsible for $57 \%$ of the new species descriptions. The same study found that while $20.3 \%$ of new species described by academics in the period 2010-2014 were based on description that included DNA sequence data, only $1.7 \%$ of those described by citizen scientists did (all were described in papers co-authored by academics). This imbalance reflects differences between academics and amateurs in access to sequencing technology and in the expertise needed to analyse DNA sequence data. In addition to using molecular sequence data in describing new taxa, critically study of previously established species hypotheses is equally important; the latter task is also hampered by the inadequacies of historical material (Bouchet \& Strong, 2010).

Malacology is thus still very much in a transitional stage: while much of the taxonomic work being carried out at present is based entirely on morphological characters, there is a parallel and slowly growing stream of integrative taxonomic research that brings together DNA sequence data and morphological data. Overall, we are still very far from the optimistic statement of May (2004), who envisioned a breakthrough in the 2010s: "advances in molecular biology accompanied by appropriate technologies will, I believe, provide us with widgets such that we can put a piece of a newly collected specimen into them, have appropriate bits of DNA sequenced, and then have the machine give us information about whether this species is indeed new to us".

In his paper introducing the concept of integrative taxonomy Dayrat (2005) proposed seven recommendations "to help integrative taxonomists recognize cases when species are supported by broad biological evidence and therefore are deserving of an official name". One of these recommendations is that "no new species names should be created if type specimens deposited in a museum collection are preserved in a way that prevents any further molecular study" (Dayrat, 2005: 412). Almost 15 years later, this recommendation is not followed by the vast majority of taxonomists, both professional and amateur. As we have shown here for E. vagrans, regardless of how morphologically distinct they appear to be, species described purely on the basis of morphologiy may potentially represent a species complex.

\section{ACKNOWLEDGEMENTS}

The material in this paper originates from deep water cruises conducted over the last 15 years by MNHN and Institut de Recherche pour le Développement (IRD) as part of the Tropical Deep-Sea Benthos programme and/or by the MNHN and Pro-Natura International (PNI) as part of the Our Planet Reviewed programme. The cruises were carried out in the following regions (PIs: Philippe Bouchet, Tin-Yam Chan, Wei-Jen Chen, Nicolas Puillandre, Sarah Samadi): Philippines (AURORA 2007), Taiwan and the South China Sea (TAIWAN 2013, NANHAI 2014, DONGSHA 2014), the Solomon Islands (SALOMON 2, SALOMONBOA 3), New Caledonia (KANACONO, KANADEEP 1), French Polynesia (TARASOC), Madagascar and Mozambique (MIRIKY, MAINBAZA, ATIMO VATAE), and Guadeloupe 
(KARUBENTHOS 2). Scientific partners included the University of Papua New Guinea, University San Carlos (Cebu City) and the Bureau of Fisheries and Aquatic Resources (Manila), Institut d'Halieutique et des Sciences Marines, University of Toliara and the Madagascar bureau of the Wildlife Conservation Society, Instituto Español de Oceanografia, the National Park of Guadeloupe, and Université des Antilles et de la Guyane Access to ship time was made possible through the Flotte Océanographique Française. Funding was provided by the Total Foundation, Prince Albert II of Monaco Foundation, Stavros Niarchos Foundation, Fonds Européen de Développement Régional and Port Autonome de la Guadeloupe. Material from Taiwan and the South China Sea was collected as part of the French-Taiwanese deep-sea project TFDeepEvo funded by ANR and NSC (ANR 12-ISV7-0005-01, PIs Sarah Samadi, Wei-Jen Chen). Yuri Kantor was supported by a grant from the Russian Science Foundation (grant number 16-14-10118; PI Y. Kantor). All expeditions operated under the regulations then in force in the countries in question. For station lists and context of the expeditions, see https://expeditions.mnhn.fr. We thank Philippe Maestrati and his team of MNHN volunteers (Danielle Plaçais, Mauricette Bourgeois, Danièle Grimal) for sorting molluscs from a vast amount of expedition material, Barbara Buge and volunteers Armelle Vaccari and Béatrice Quinet for curating molecular vouchers, and Virginie Héros for carefully checking the manuscript, registering material and databasing associated locality data.

\section{REFERENCES}

BARNARD, K.H. 1959. Contributions to the knowledge of South Africa marine Mollusca. Part II. Gastropoda: Prosobranchiata: Rhachiglossa. Annals of the South African Museum, 45: 1-237.

BOUCHET, P., BARY, S., HÉROS, V. \& MARANI, G. 2016. How many species of molluscs are there in the world's oceans, and who is going to describe them? In: tropical deep-sea benthos 29. Muséum national d'Histoire naturelle, Paris (V. Héros, E. Strong \& P. Bouchet, eds), pp. 9-24 (Mémoires du Muséum national d'Histoire naturelle ; 208). .

BOUCHET, P., LOZOUET, P., MAESTRATI, P. \& HEROS, V. 2002. Assessing the magnitude of species richness in tropical marine environments: high numbers of molluscs at a New Caledonia site.

Biological Journal of the Linnean Society, 75: 421-436.

BOUCHET, P. \& ROCROI, J.-P. 2005. Classification and nomenclator of gastropod families. Malacologia, 47: 1-397.

BOUCHET, P. \& Strong, E.S. 2010. Historical name-bearing types in marine molluscs. An impediment to biodiversity studies? In: Systema Naturae 250 (A. Polaszek, ed.), pp. 63-74. CRC Press, London, $\underline{\mathrm{UK}}$.

BOZZETTI, L. 2001. Tre nuove specie (Mollusca, Gastropoda) dal Madagascar sud-ocidentale. Malacologia Mostra Mondiale, 33: 17-19.

DAYRAT, B. 2005. Towards integrative taxonomy. Biological Journal of the Linnean Society, 85: 407415.

DRUMMOND, A.J., SUCHARD, M.A., XIE, D. \& RAMBAUT, A. 2012. Bayesian phylogenetics with BEAUti and the BEAST 1.7. Molecular Biology and Evolution, 29: 1969-1973

FEDOSOV, A., PUILLANDRE, N., KANTOR, Y. \& BOUCHET P. 2015. Phylogeny and systematics of mitriform gastropods (Mollusca: Gastropoda: Neogastropoda). Zoological Journal of the Linnean Society, 175: 336-359. 
FEDOSOV A. E., STAHLSCHMIDT P., PUILLANDRE N., AZNAR-CORMANO L. \& BOUCHET P. 2016. Not all spotted cats are leopards: evidence for a Hemilienardia ocellata species complex (Gastropoda: Conoidea: Raphitomidae). European Journal of Taxonomy, 268: 1-20.

FONTAINE, B. et al. (51 authors). 2012. New species in the Old World: Europe as a frontier in biodiversity exploration, a test bed for 21st century taxonomy. PLoS One, 7: e36881.

GALINDO L.A., PUILLANDRE N., STRONG E.E. \& BOUCHET, P. 2014. Using microwaves to prepare gastropods for DNA barcoding. Molecular Ecology Resources, 14: 700-705.

HABE, T. 1952. Pholadomyidae, Clavagellidae, Pandoridae, Juliidae and Condylocardiidae in Japan. Illustrated catalogue of Japanese shells, 18: 121-132.

HIGO, S., CALLOMON, P. \& GOTO, Y. 1999 Catalogue and bibliography of the marine shell-bearing Mollusca of Japan. Elle Scientific Publications, Osaka.

HUELSENBECK, J.P., RONQUIST F. \& HALL, B. 2001. MrBayes: Bayesian inference of phylogeny. Bioinformatics, 17: 754-755.

KANTOR, Y.I., BOUCHET, P. \& OLEINIK, A. 2001. Recent Benthovoluta is congeneric with fossil Exilia (Gastropoda: Turbinellidae), with a revision of the Recent species. Ruthenica, 11: 81-136.

KANTOR, Y.I., FEDOSOV, A. \& PUILLANDRE, N. 2018. New and unusual deep-water Conoidea revised with shell, radula and DNA characters. Ruthenica, 28: 47-82.

KANTOR, Y.I., STAHLSCHMIDT, P., AZNAR-CORMANO, L., BOUCHET, P. \& PUILLANDRE, N. 2017. Too familiar to be questioned? Revisiting the Crassispira cerithina species complex (Gastropoda: Conoidea: Pseudomelatomidae). Journal of Molluscan Studies, 83: 43-55.

KURODA, T. 1931. Two new species of Volutacea. Venus, 3: 45-49.

MARTENS, E. Von. 1897. Conchologische Miscellen. Archiv für Nasturgeschichte, 63: 157-180, pls 1517.

MAY, R. M. 2004. Tomorrow's taxonomy: collecting new species in the field will remain the rate-limiting step. Philosophical Transactions of the Royal Society of London B, 359: 733-734.

MONAGHAN, M.T., WILD, R., ELLIOT, M., FUJISAWA, T., BALKE, M., INWARD, D.J., LEES D.C., RANAIVOSOLO, R., EGGLETON, P., BARRACLOUGH T.G. \& VOGLER, A.P. 2009.

Accelerated species inventory on Madagascar using coalescent-based models of species delineation. Systematic Biology, 58: 298-311.

OKUTANI, T. 2000 Marine mollusks in Japan. Tokai University Press, Tokyo, Japan.

OKUTANI, T. 2017 Marine mollusks in Japan, ed. 2. Tokai University Press, Tokyo, Japan.

PONS J., BARRACLOUGH, T.G., GOMEZ-ZURITA J., CARDOSO, A., DURAN, D.P., HAZELL, S., KAMOUN, S., SUMLIN, W.D. \& VOGLER, A.P. 2006. Sequence-based species delimitation for the DNA taxonomy of undescribed insects. Systematic Biology, 55: 595-609.

PUILLANDRE, N., SYSOEV, A.V., OLIVERA B.M., COULOUX A. \& BOUCHET P. 2010a. Loss of planktotrophy and speciation: geographical fragmentation in the deep-water gastropod genus

Bathytoma (Gastropoda, Conoidea) in the western Pacific. Systematics and Biodiversity, 8: 371-394.

PUILLANDRE, N., CRUAUD, C. \& KANTOR, Y.I. 2010b. Cryptic species in Gemmuloborsonia (Gastropoda: Conoidea). Journal of Molluscan Studies, 76: 11-23.

PUILLANDRE, N., LAMBERT, A., BROUILLET, S. \& ACHAZ, G. 2012. ABGD, automatic barcode gap discovery for primary species delimitation. Molecular Ecology, 21: 1864-1877.

PUILLANDRE, N., FEDOSOV, A.E., ZAHARIAS, P., AZNAR-CORMANO, L. \& KANTOR, Y.I. 2017. A quest for the lost types of Lophiotoma (Gastropoda: Conoidea: Turridae): integrative taxonomy in a nomenclatural mess. Zoological Journal of the Linnean Society, 181: 243-271. 
RAMBAUT, A. \& DRUMMOND, A.J. 2014. Tracer v. 1.6. Available at: http://beast.bio.ed.ac.uk/Tracer RIEDEL, F., 2000, Ursprung und Evolution der 'höheren' Caenogastropoda. Berliner Geowissenschaftliche Abhandlungen, E 32: 1-240.

SANDERS, M.T., MERLE, D., BOUCHET, P., CASTELIN, M., BEU, A.G., SAMADI, S. \& PUILLANDRE, N. 2017. One for each ocean: revision of the Bursa granularis (Röding, 1798) species complex (Gastropoda: Tonnoidea: Bursidae). Journal of Molluscan Studies, 83: 384-398.

SOGIN M.L., MORRISON, H.G., HUBER J.A., WELCH, D.M., HUSE, S.M., NEAL, P.R., ARRIETA, J.M., and HERNDL, G.H.. 2006. Microbial diversity in the deep sea and the underexplored "rare biosphere". Proceedings of the National Academy of Sciences of the USA, 103: 12115-12120.

STAMATAKIS, A. 2006. RAxML-VI-HPC: maximum likelihoodbased phylogenetic analyses with thousands of taxa and mixed models. Bioinformatics, 22: 2688-2690.

TAMURA, K., STECHER, G., PETERSON, D., FILIPSKI, A. \& KUMAR, S. 2013. MEGA6: molecular evolutionary genetics analysis version 6.0. Molecular Biology and Evolution, 30: 2725-2729.

YOKOYAMA, M. 1920. Fossils from the Miura Peninsula and its immediate north. Tokyo Imperial University, College of Science Journal, 39: 1-193, pls 1-19. 


\section{Captions for figures}

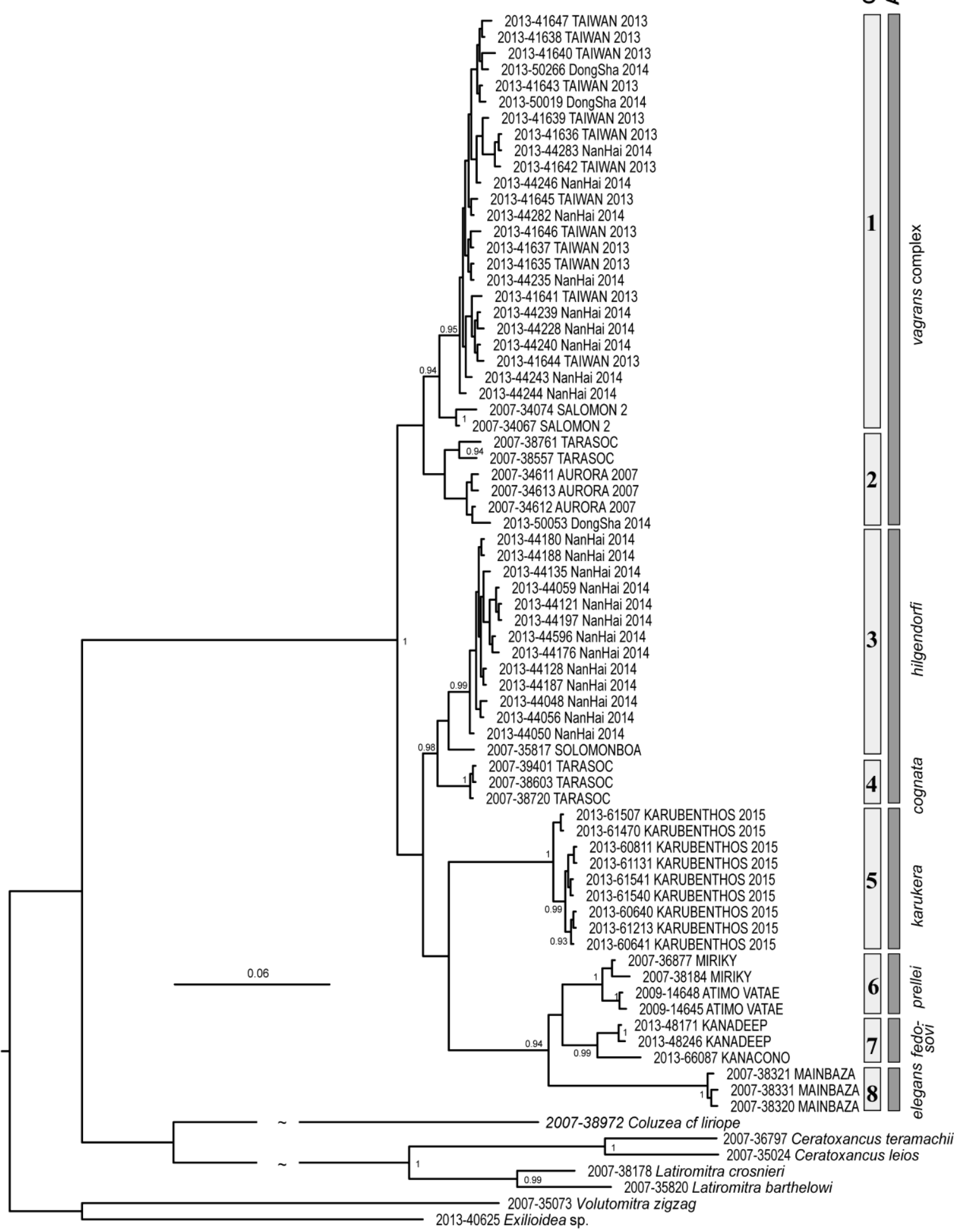

Figure 1. Bayesian tree, as generated by MrBayes, for the COI gene. PP values $>0.90$ are shown for the relevant branches. The bars to the right of the tree show the putative species as delimited by GMYC (light grey) and ABDG (dark grey) methods. Scale bar indicates substitutions per site. 


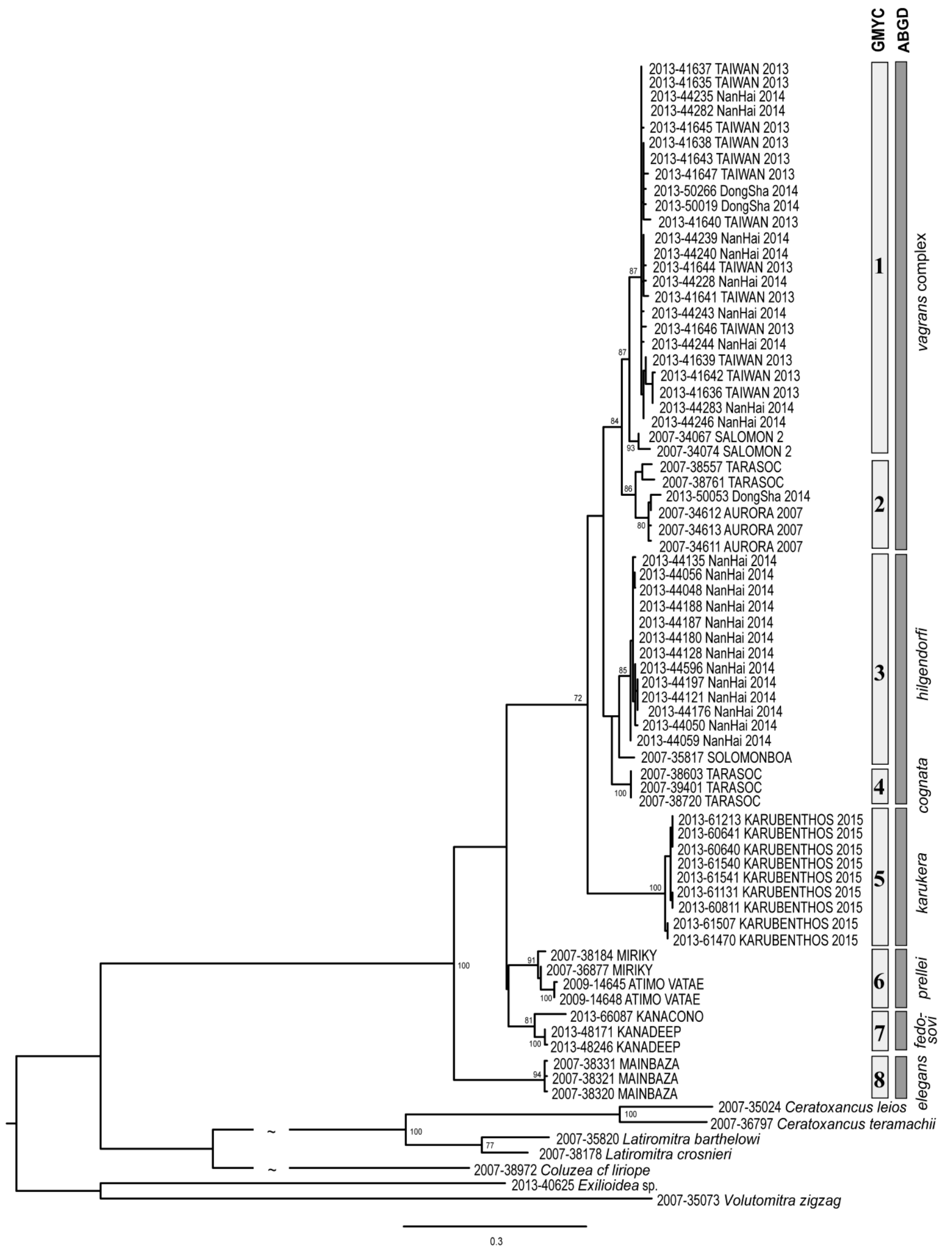

Figure 2. ML tree for the COI gene. BS values $>70 \%$ are shown for relevant branches. The bars to the right of the tree show the putative species as delimited by GMYC (light grey) and ABDG (dark grey) methods. Scale bar indicates substitutions per site. 


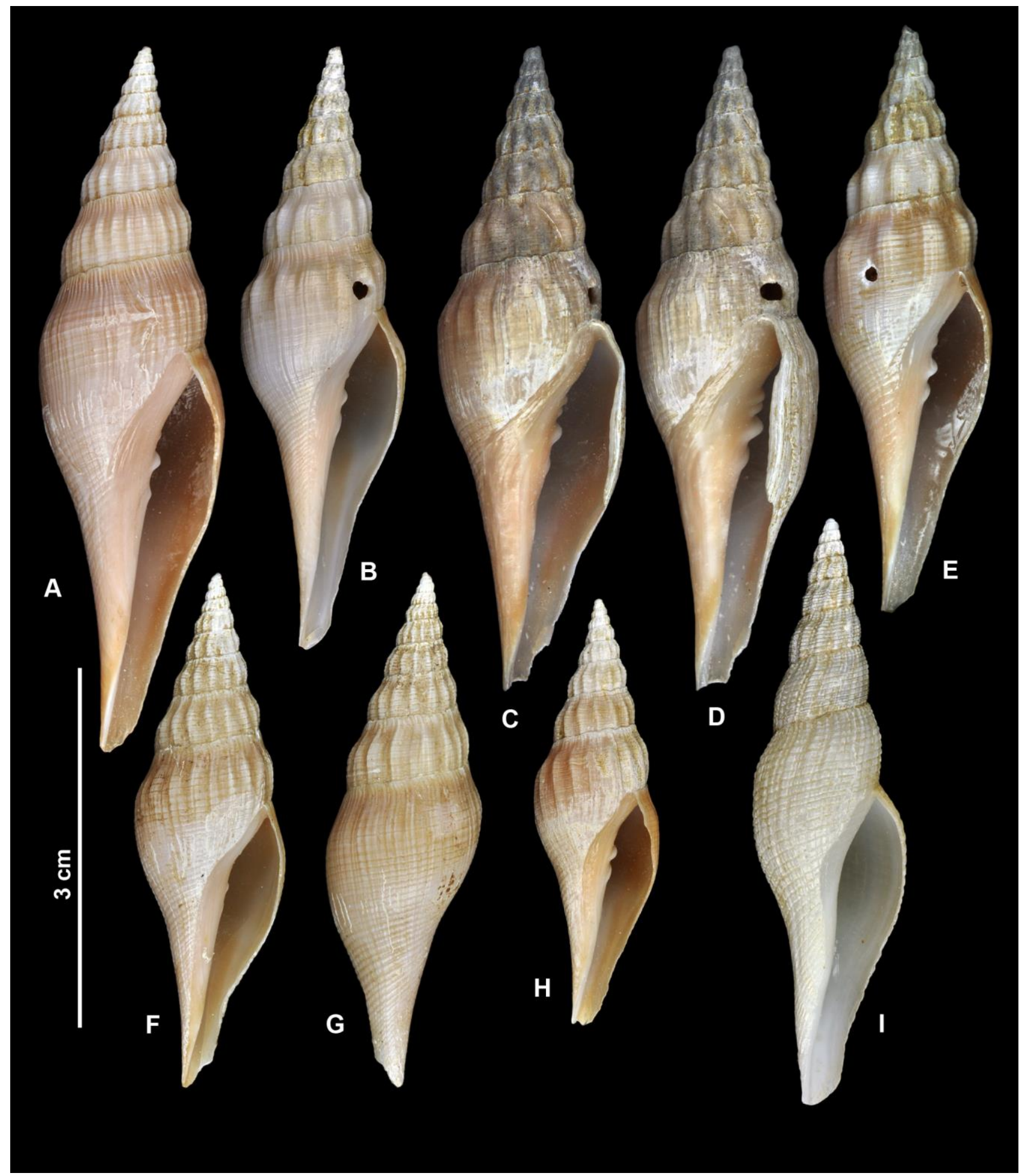

Figure 3. A-H. Exilia hilgendorfi. A. MNHN IM-2013-44048, SL 59.6 mm. B. MNHN IM-2013-44059, SL 51 mm. C, D. MNHN IM-2013-44412, SL 54.9 mm. E. MNHN IM-2013-44596, SL 49.6 mm. F, G. MNHN IM-2013-44180, SL 43.4 mm. H. MNHN IM-2013-44128, SL 35.9 mm. I. Exilia elegans, MNHN IM-2007-38302, SL $40.3 \mathrm{~mm}$. All shells except I are shown at the same scale. 


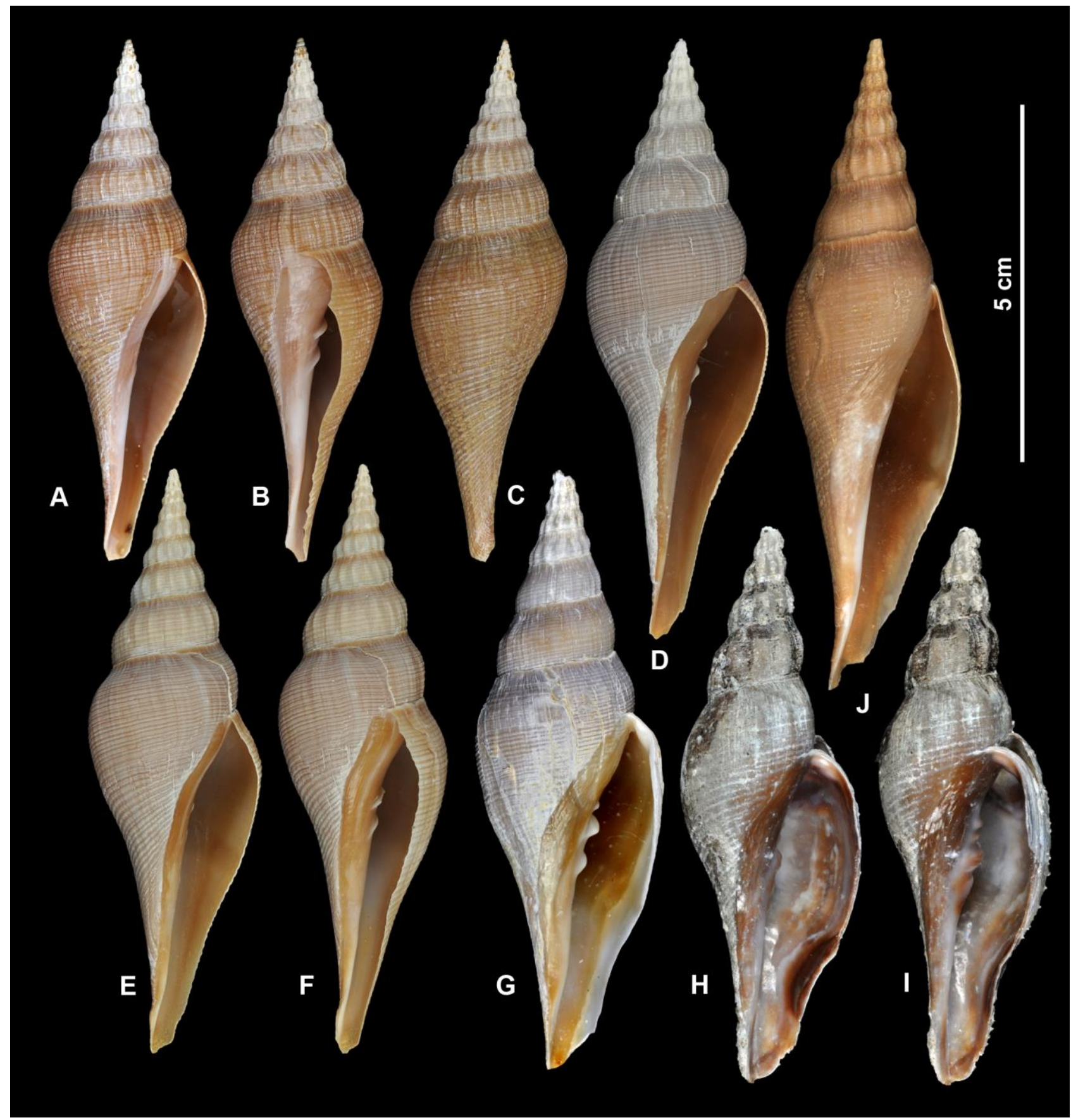

Figure 4. Exilia hilgendorfi. A-C. Solomon Islands, MNHN IM-2007-35817, SL 73.7 mm (sequenced specimen); B shows the shell rotated slightly clockwise to show the columellar plaits. D. Solomon Islands, MNHN IM-2007-34057, SL 84.5 mm (not sequenced). E, F. Solomon Islands, MNHN IM-2007-34061, SL $82.7 \mathrm{~mm}$ (not sequenced); $\mathbf{F}$ shows the shell rotated slightly clockwise to show the columellar plaits. $\mathbf{G}$. Solomon Islands, MNHN IM-2007-34058, SL 84.4 mm (not sequenced). H, I. Japan, Uraga Channel, MNHN IM-2019-902, SL $78.2 \mathrm{~mm}$; I shows the shell rotated slightly clockwise to show the columellar plaits. J. Exilia aff. hilgendorfi, Tonga, BORDAU 2, Stn CP1640, $21^{\circ} 09^{\prime} \mathrm{S}, 175^{\circ} 24^{\prime} \mathrm{W}, 564-569 \mathrm{~m}$, SL $91.9 \mathrm{~mm}$. 

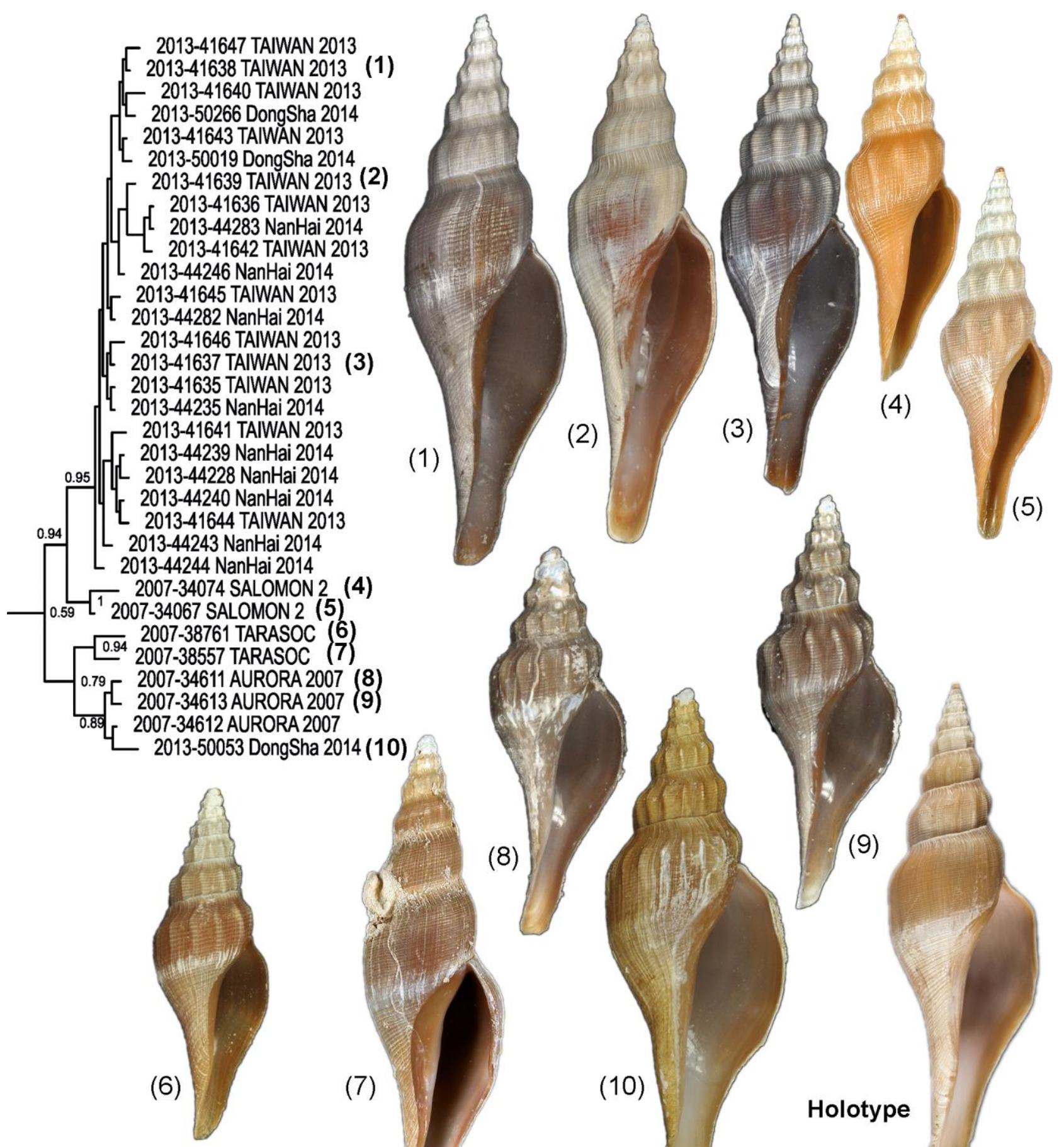

(7)

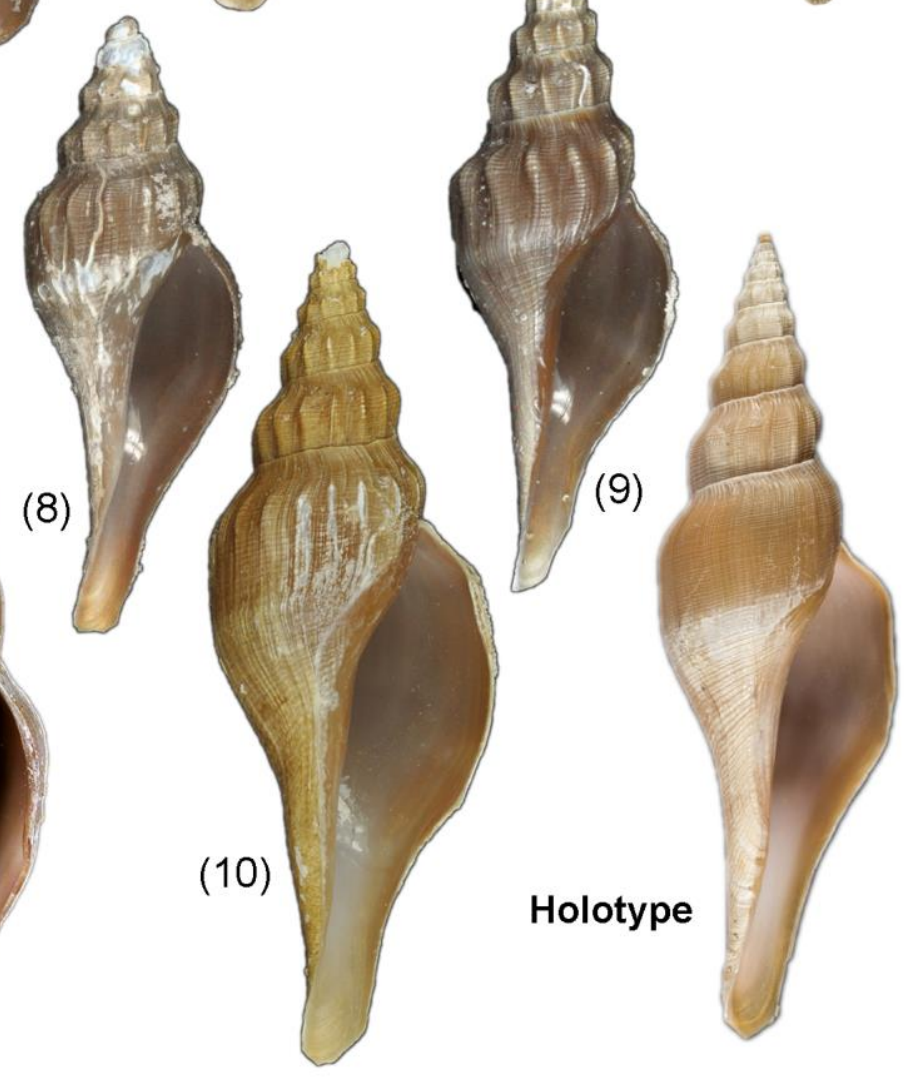

Figure 5. Exilia vagrans complex as shown in the Bayesian tree. The numbers within parentheses correspond to the illustrated shells: (1). MNHN IM-2013-41638, SL 56.4 mm; (2) MNHN IM-2013-41639, SL 56.4 mm; (3). MNHN IM-2013-41637, SL 50.2 mm; (4) MNHN IM-2007-34074, SL 32.3 mm; (5). MNHN IM-2007-34067, SL 34.2 mm; (6). MNHN IM-2007-38761, SL $27.1 \mathrm{~mm}$; (7). MNHN IM-200738557, SL 50.4 mm; (8). MNHN IM-2007-34611, SL 35 mm; (9). MNHN IM-2007-34613, SL 38.1 mm; and (10). MNHN IM-2013-50053, SL $51.3 \mathrm{~mm}$. The holotype (MNHN IM-2000-20028, SL 53.5 mm) is shown for comparison. Shells not shown to scale. 

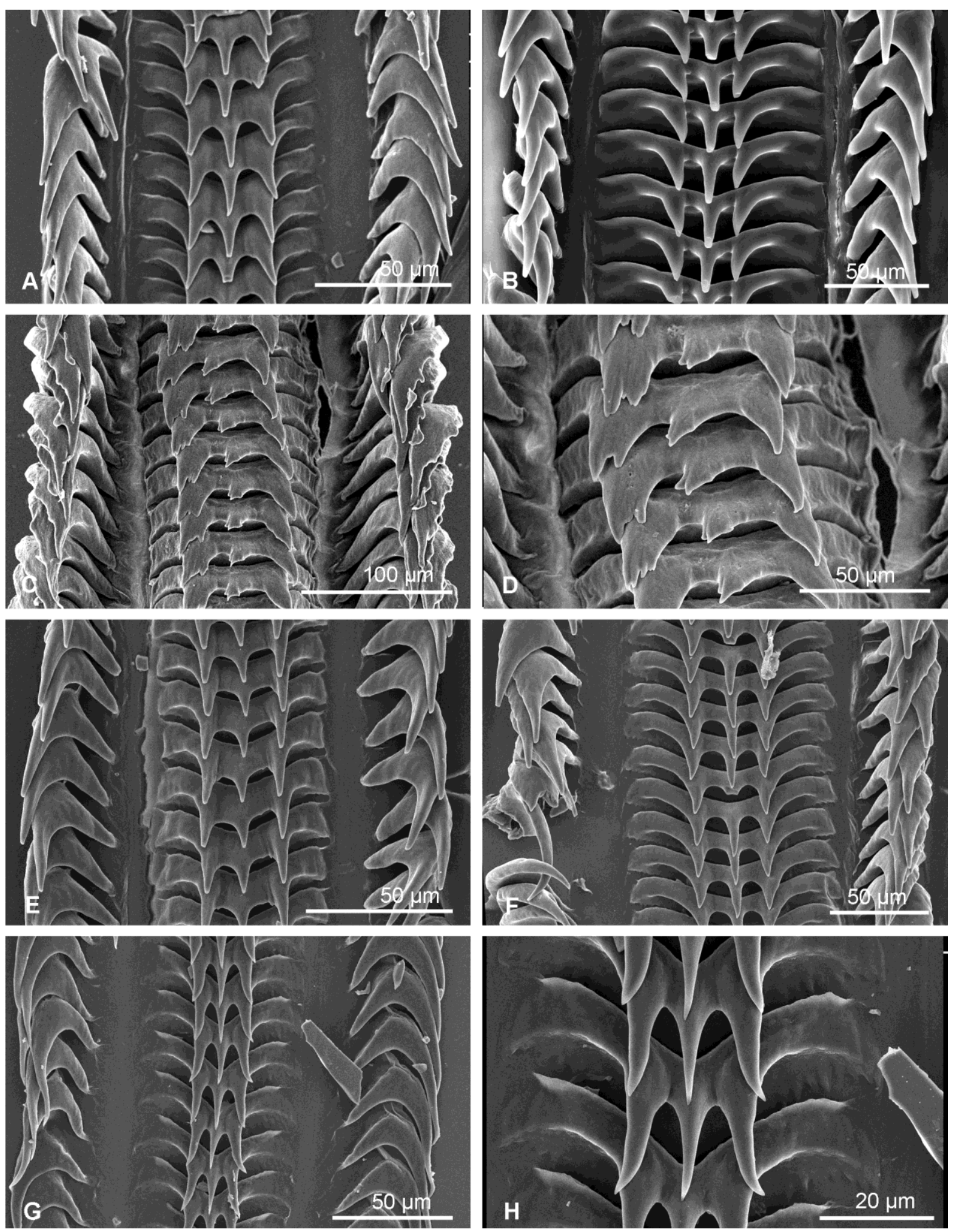

Figure 6. Radulae of the genus Exilia A, C-D. Exilia hilgendorfi. A. MNHN IM-2013-44180, SL $43.4 \mathrm{~mm}$ (sequenced specimen, shell shown in Fig. 3F-G). C, D. MNHN IM-2007-36332, SL 88.7 mm. B. Exilia elegans, MNHN IM- 2007-38331, shell broken, SL unknown. E. Exilia fedosovi sp. nov., Coral Sea, MNHN IM-2013-48171, SL 23.7 mm (sequenced specimen, shell shown in Fig. 9D-F). Image: A. Fedosov. F. Exilia aff. fedosovi, Norfolk Ridge, MNHN IM-2013-66087, SL 31.9 mm (sequenced specimen, shell shown in Fig. 9H-I). G, H. Exilia karukera sp. nov., holotype MNHN IM-2013-61213 (shell shown in Fig. 7A-C). 


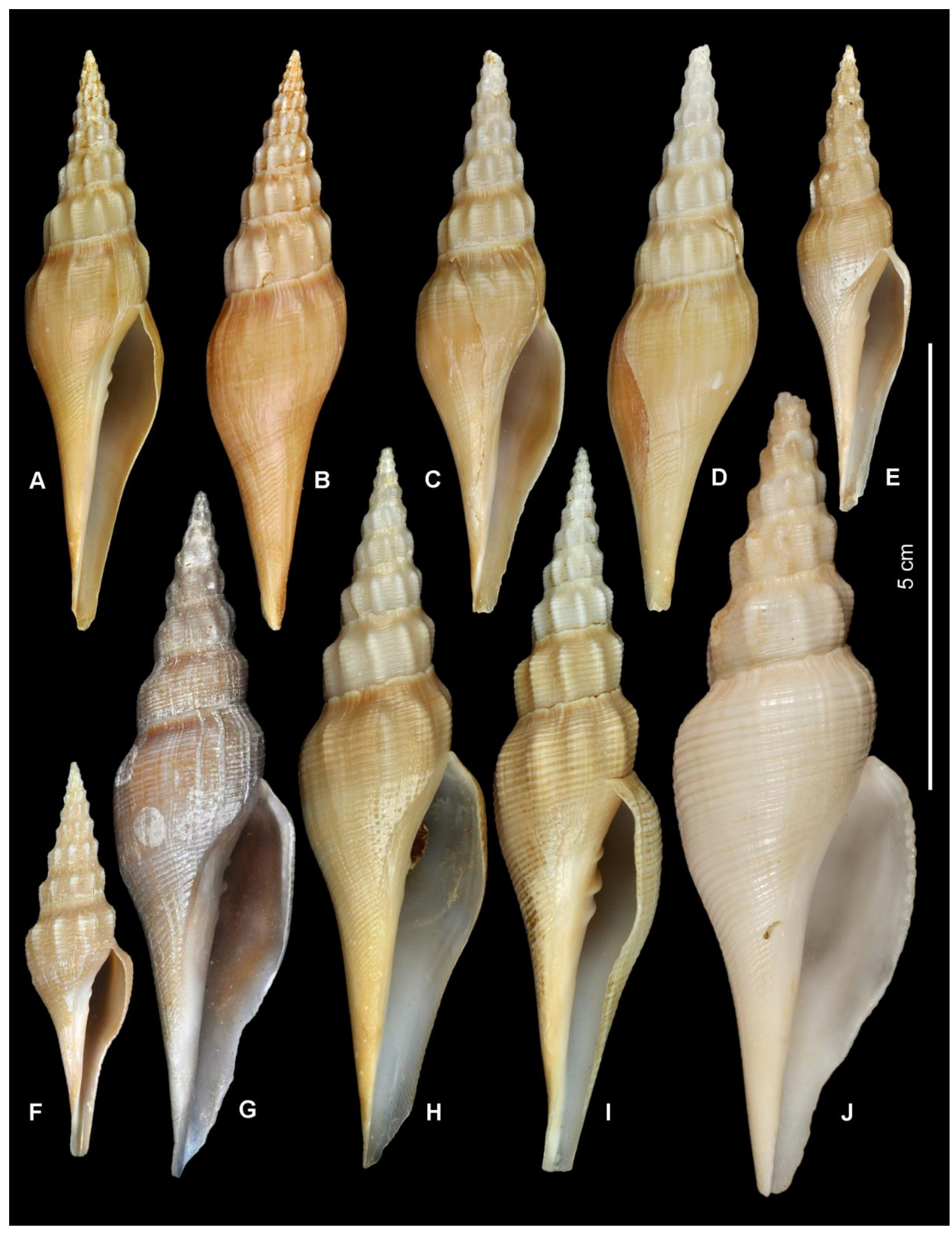

Figure 7. Exilia prellei. A, B. South Madagascar, MNHN IM-2009-14645, SL 64.9 mm (sequenced specimen). C, D. South Madagascar, MNHN IM-2009-14648, SL 64 mm. E. North Madagascar, MNHN IM-2007-36877, SL 52.4 mm (sequenced specimen). F. North Madagascar, MNHN IM-2007-38184, SL $44.7 \mathrm{~mm}$ (sequenced specimen). G. North Madagascar, MNHN IM-2007-36825, SL 77.4 mm (not sequenced). H, I. West Madagascar, Mascareignes III, Stn 75, SL $81.5 \mathrm{~mm}$ (not sequenced); I shows the shell rotated slightly clockwise to show the columellar plaits. J. Benthovoluta prellei Bozetti, 2001, holotype, Madagascar, off Tulear, MNHN IM-2000-30286, SL 90.5 mm. 


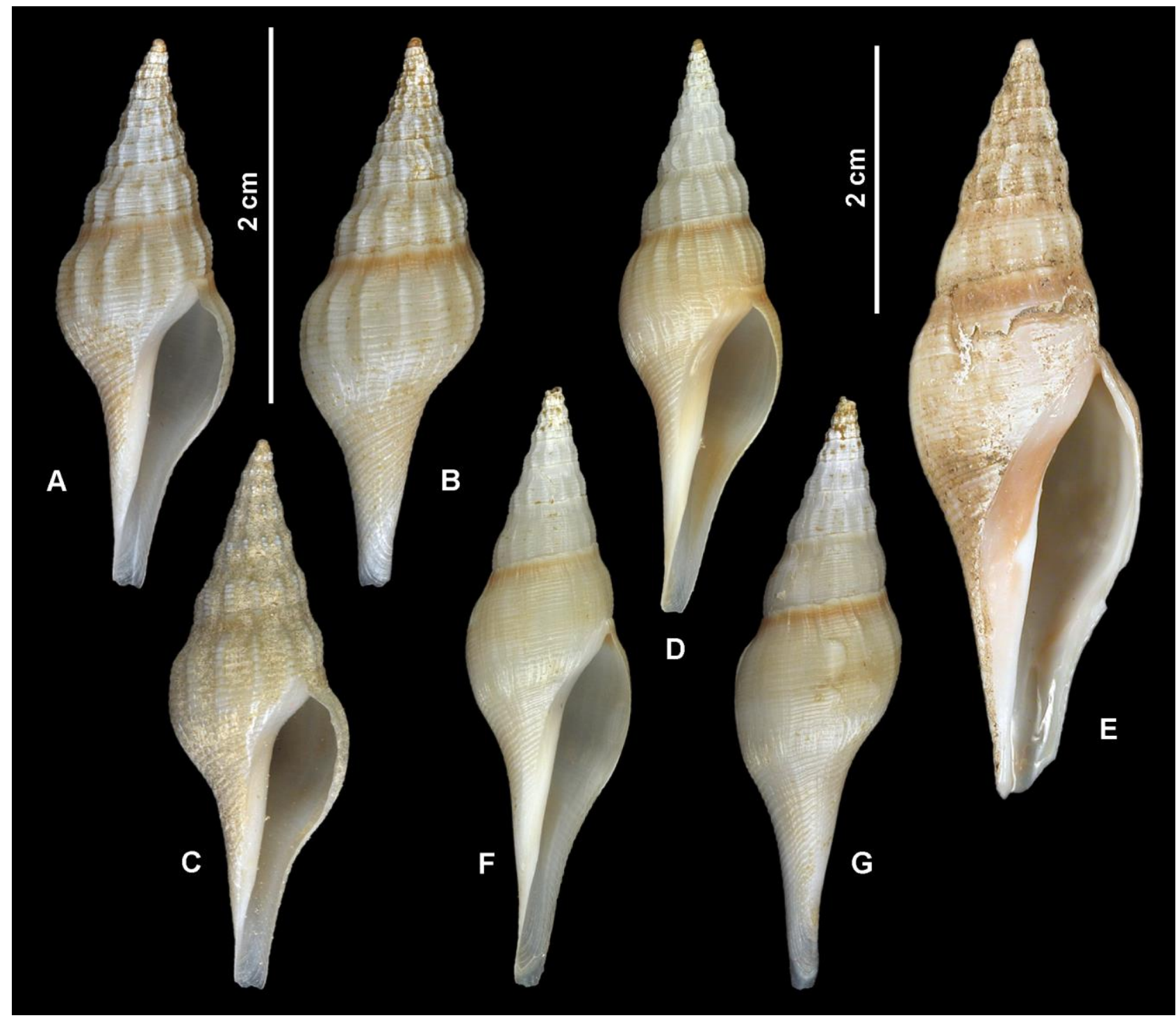

Figure 8. Exilia cognata new species. A-C. Holotype, MNHN IM-2007-38720, Society Islands, SL 29.5 $\mathrm{mm}$ (sequenced specimen); A-B shows apertural and dorsal views of the cleaned shell, $\mathrm{C}$ shows apertural view of shell prior to cleaning. D. Society Islands, MNHN IM-2007-38702, SL $43.0 \mathrm{~mm}$ (not sequenced). E. Society Islands, MNHN IM-2007-38603, SL 57.8 mm (sequenced specimen). F, G. Society Islands, MNHN IM-2007-38703, SL 45.6 mm (not sequenced). A-C. Shown at higher magnificationin comparison to other shells. 


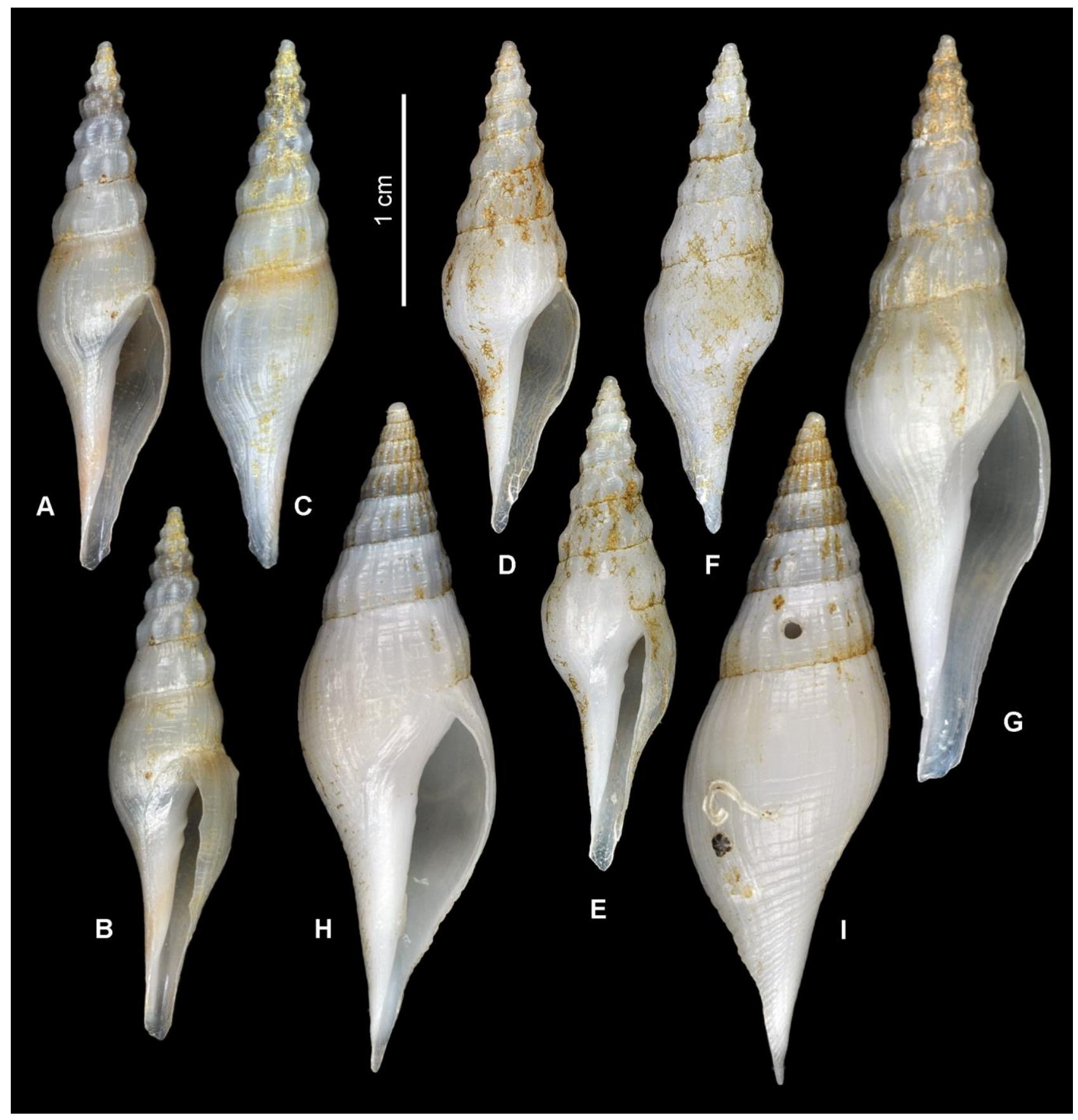

Figure 9. Exilia fedosovi new species. A-C. Holotype, Coral Sea, MNHN IM-2013-48246, SL 25.5 mm (sequenced specimen); B shows shell turned slightly clockwise relative to apertural view so that the columellar plaits are clearly visible. D, F. Coral Sea, MNHN IM-2013-48171, SL 23.7 mm (sequenced specimen, radula shown in Fig. 4E); E shell turned slightly clockwise relative to apertural view so that the columellar plaits are clearly visible. G. Coral Sea, MNHN IM-2013-65654, SL 35.5 mm (not sequenced). H, I. Exilia if. fedosovi sp. nov., Norfolk Ridge, MNHN IM-2013-66087, SL 31.9 mm (sequenced specimen).

29 


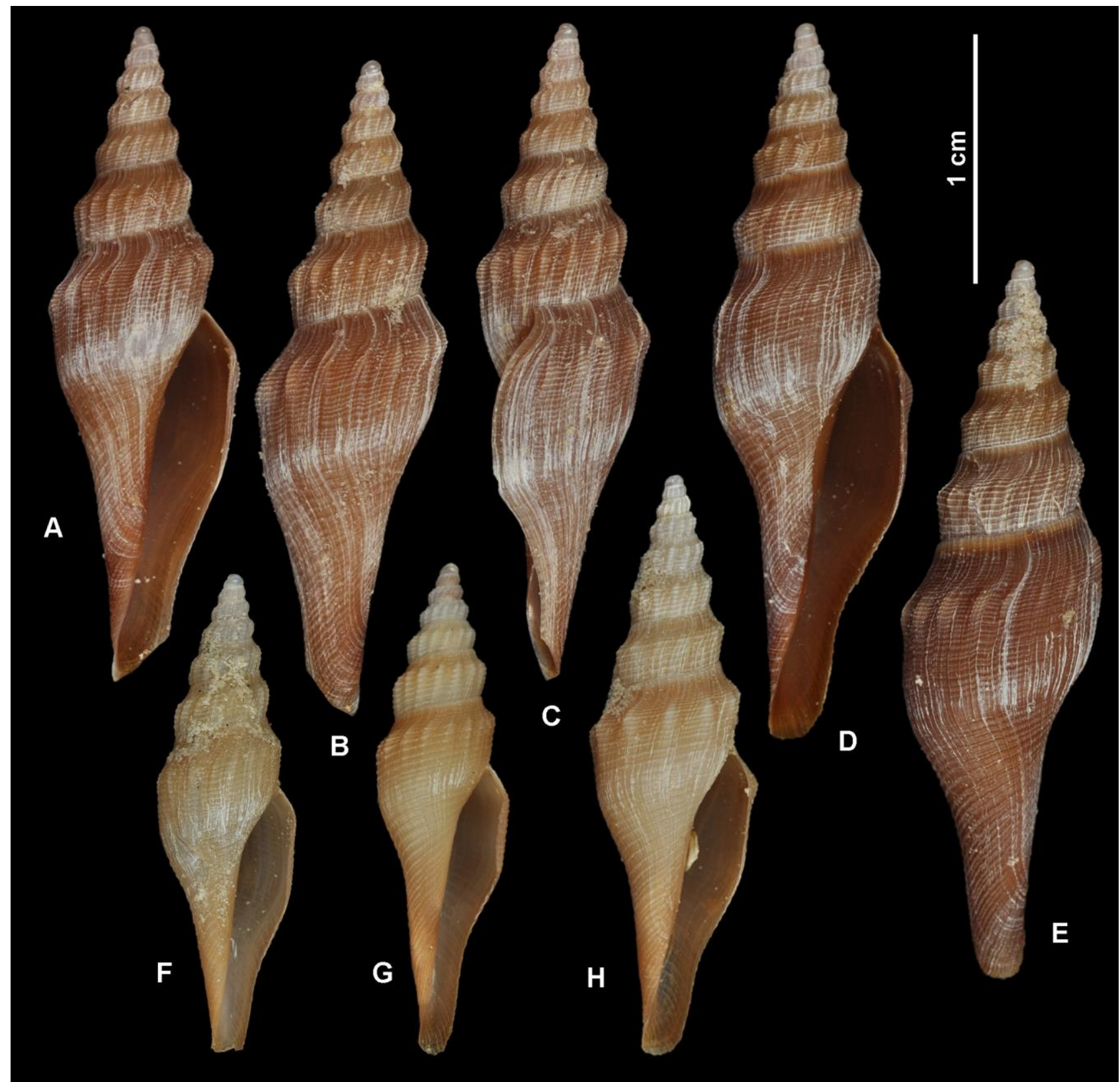

Figure 10. Exilia karukera n. sp, Guadeloupe (all specimens shown have been sequenced). A-C. Holotype, MNHN IM-2013-61213, SL 26.8 mm (for radula see Fig. 4G-H). D, E. MNHN IM-2013-61541, SL 29.3 mm. F. MNHN IM-2013-60811, SL 19.4 mm. G. MNHN IM-2013-61470, SL 20 mm. H. MNHN IM2013-61540, SL $23.5 \mathrm{~mm}$. All shells are shown at the same scale. 